NBER WORKING PAPER SERIES

IS THE WASHINGTON CONSENSUS DEAD? GROWTH, OPENNESS, AND THE
GREAT LIBERALIZATION, 1970S-2000S

Antoni Estevadeordal

Alan M. Taylor

Working Paper 14264

http://www.nber.org/papers/w14264

\author{
NATIONAL BUREAU OF ECONOMIC RESEARCH \\ 1050 Massachusetts Avenue \\ Cambridge, MA 02138
}

August 2008

This research was kindly supported by the Inter-American Development Bank and by the Center for the Evolution of the Global Economy at the University of California, Davis. Taylor also thanks the Center for Economic Performance at the London School of Economics, where some of the work on this project was also undertaken. Matthew Shearer, Mari Nishie, and Seema Sangita provided research assistance for which we are very grateful. For useful comments and help with data we thank Laura Alfaro, Robert Feenstra, Ann Harrison, Douglas Irwin, Dani Rodrik, John Romalis, Andrew Rose, and seminar participants at the Harvard Business School BGIE group. All errors are ours. The views expressed herein are those of the author(s) and do not necessarily reflect the views of the National Bureau of Economic Research.

NBER working papers are circulated for discussion and comment purposes. They have not been peerreviewed or been subject to the review by the NBER Board of Directors that accompanies official NBER publications.

(C) 2008 by Antoni Estevadeordal and Alan M. Taylor. All rights reserved. Short sections of text, not to exceed two paragraphs, may be quoted without explicit permission provided that full credit, including (C) notice, is given to the source. 
Is the Washington Consensus Dead? Growth, Openness, and the Great Liberalization, 1970s-2000s Antoni Estevadeordal and Alan M. Taylor

NBER Working Paper No. 14264

August 2008

JEL No. E65,F10,F13,F43,F53,N10,N70,O40

\begin{abstract}
According to the Washington Consensus, developing countries' growth would benefit from a reduction in tariffs and other barriers to trade. But a backlash against this view now suggests that trade policies have little or no impact on growth. If "getting policies right" is wrong or infeasible, this leaves only the more tenuous objective of "getting institutions right" (Easterly 2005, Rodrik 2006). However, the empirical basis for judging recent trade reforms is weak. Econometrics are mostly ad hoc; results are typically not judged against models; trade policies are poorly measured (or not measured at all, as when trade volumes are spuriously used); and the most influential studies in the literature are based on pre-1990 experience (which predates the "Great Liberalization" in developing countries which followed the GATT Uruguay Round). We address all of these concerns -- by using a model-based analysis which highlights tariffs on capital and intermediate goods; by compiling new disaggregated tariff measures to empirically test the model; and by employing a treatment-and-control empirical analysis of pre- versus post-1990 performance of liberalizing and nonliberalizing countries. We find evidence that a specific treatment, liberalizing tariffs on imported capital and intermediate goods, did lead to faster GDP growth, and by a margin consistent with theory (about 1 percentage point per annum). Endogeneity problems are considered and other observations are consistent with the proposed mechanism: changes to other tariffs, e.g. on consumption goods, though collinear with general tariffs reforms, are more weakly correlated with growth outcomes; and the treatment and control groups display different behavior of investment prices and quantities, and capital flows.
\end{abstract}

Antoni Estevadeordal

Integration and Trade Sector

Inter-American Development Bank

1300 New York Avenue, N.W.

Washington, D.C. 20577

ANTONIE@IADB.ORG

\author{
Alan M. Taylor \\ Department of Economics \\ University of California, Davis \\ One Shields Avenue \\ Davis, CA 95616 \\ and NBER \\ amtaylor@ucdavis.edu
}


Does trade policy liberalization promote economic growth? The question has been central to recent economic policy debates since the dawn of the new era of globalization in the 1990s. Yet the opinions of economists, once quite coherent, are now far from unanimous.

In the 1990s the so-called "Washington Consensus" (WC) promoted openness to trade as an essential policy reform to promote growth and higher incomes. ${ }^{1}$ At first, absent statistical evidence, this view garnered support as practitioners looked back on the divergent economic fortunes of the fast-growing export-oriented New Industrializing Countries (NICs) of East Asia and the sluggish inward-looking economies of Latin America. Subsequently, a barrage of crosscountry econometric studies seemed to lend weight to this view, including well known and widely cited works by Dollar (1992), Sachs and Warner (1995), Edwards (1998), and Frankel and Romer (1999). It was in this intellectual climate that trade barriers fell in many developing countries all over the world in the "Great Liberalization" of the 1990s.

A decade later whatever consensus there might have been, appears lost. A recent survey of the World Bank's self-review Learning from Reform by Rodrik (2006) is entitled "Goodbye Washington Consensus, Hello Washington Confusion." The survey notes that some still believe that the problem was too little reform, rather than too much; but once one gets past the few hold outs (e.g., the IMF), it seems that if there is any sort of new consensus in Washington it is one where the focus has shifted from getting policies right (the "policy view") to getting institutions right (the "institutions view"), although the practical implications of that shift are quite unclear (Easterly 2005). The one-line abstract on Rodrik's website sums up the current mood: "The Washington Consensus is dead. What will take its place?"

It would be a mistake to equate trade liberalization with the entire Washington Consensus; but, of the ten reforms in the original WC package, trade policy seems to have attracted the most attention. Why? On trade policy, the political stakes appear high-protests and riots accompany WTO meetings but there is not such violent agitation over other issues in the WC package; and no doubt the other elements of the WC are uncontroversial-e.g., nobody is now arguing for fiscal indiscipline or insecure property rights.

In the research arena, the openness-growth linkage has also attracted a vast amount of attention, probably more than any other element of the Washington Consensus. It is also where the apparent reversal of sentiment has been most dramatic. Academic research has played no small part in this revolution. Rodríguez and Rodrik (2001) replicated and extended the above heavily cited works from the 1990s to assess their robustness - and found them wanting. Theirs is now another widely referenced work that lends weight to an increasingly prevalent view that trade policies may have very little to do with economic performance. ${ }^{2}$ Moreover, in later work by

\footnotetext{
${ }^{1}$ In fairness to Williamson (1990), his WC recommendations were a broad and coherent package of ten reforms, of which trade reforms were just a part. We say "so-called" because the term "Washington Consensus" soon took on a life of its own. The ten reforms were summarized by Rodrik $(2006,978)$ as: fiscal discipline; reorientation of public expenditures; tax reform; financial liberalization; unified and competitive exchange rates; trade liberalization; openness to FDI; privatization; deregulation; and secure property rights.

${ }^{2}$ Rodríguez and Rodrik focus on the papers by Sachs and Warner, Frankel and Romer, Edwards and Dollar because these papers were most influential in terms of impact. For example, the citation counts as of July 2008 were: Sachs
} 
Easterly, Rodrik and others, institutions have been proposed as the "deeper determinants" that have been said to trump other factors such as trade policies (Easterly and Levine 2003; Rodrik, Subramanian, and Trebbi 2004; Easterly 2005).

The latest findings might have laid to rest the debate about growth and trade policy, but we argue that the jury is still out. As noted by Rodríguez and Rodrik (2001), cross-section empirical work to date has depended on dubious and noisy data. Confidence intervals were generally large and not far from zero. It was therefore relatively easy to find results that would disappear under alternative assumptions or with a different set of controls. Of course, imprecision does not mean that there is no effect, only that our tests are weak and we have not yet been able to measure precisely enough to answer the question-and the coefficient estimates of skeptics like Rodríguez and Rodrik (2001) are just as subject to this critique as those of the earlier literature. Thus the tariff-growth literature has reached an apparent impasse. Unclear results meant that neither side can really claim victory, so policy debates over the merits of a key element of the Washington Consensus are still unresolved.

As far as trade policy is concerned, if the reports of the death of the Washington Consensus might be exaggerated, can we make any further progress? We think so, if only because so much time has now passed since the first round of empirical studies. As the academic and policy community now judges the Washington Consensus, one troubling aspect of the most cited papers in the literature on openness and growth, both pro and con, is that they all base their tests on data drawn from periods before 1990: before the Washington Consensus had even emerged, and before the "Great Liberalization" in trade policy in the 1990s had taken root in most developing countries, following the completion of the Uruguay Round and the rise of politics more sympathetic to free markets. This problem affects the datasets in Frankel and Romer (spanning 1960-85), Edwards (1960-89), Sachs and Warner (1970-89), and Dollar (1970-89), as well as all of the robustness checks of these studies in Rodríguez and Rodrik. But now, more than 15 years after the end date of the last generation of studies, we ought to be in a position to judge the effects of the experiment that was the Washington Consensus as it has run from 1990 onwards. And we ought to do so using sounder tests and harder data. ${ }^{3}$

In this paper, we do just that-we document the "Great Liberalization" experiment and study its correlation with before-and-after growth outcomes in two windows, 1975-89 and 1990-2004. For sure, skeptical studies, notably Rodríguez and Rodrik (2001) and Easterly (2005), have set a higher bar for future empirical work, a bar which we now endeavor to surmount. We agree with them that the data and the techniques used by all sides in the debate thus far have been inadequate in a number ways, most notably:

and Warner 2212; Frankel and Romer 1658; Edwards 901; Dollar 616. Rodríguez and Rodrik had 1367 citations, making theirs the dominant paper with the opposing viewpoint. Citation counts from scholar.google.com.

${ }^{3}$ Even within the confines of cross-sectional empirical work the debate has moved on from the works surveyed by Rodrik and Rodríguez (2001). More recent papers arguing for a positive effect of trade on growth include Alcalá and Ciccone (2004), Noguer and Siscart (2005), and Warner (2003). In turn, the skeptics have made further responses: see Rodríguez (2007). 
- The data are scant in terms of spatial and temporal coverage; the latter encouraged crosssection OLS estimation which is plagued by omitted-variable and endogeneity problems;

- The trade policy measures were subject to measurement error or subjective bias;

- They were often endogenous "outcome" measures (like trade volume) that did not correspond to any trade policy measure that was directly controlled by policymakers;

- They did not correspond to any trade policy measure that would be suggested by theory as having a causal impact on growth;

- They were not robustly correlated with growth outcomes, and appeared to be trumped by institutions.

Hence, in this paper we aim to confront all of these issues and develop an improved methodology and dataset for studying the tariff-growth question. We pay attention to theory and seek tariff measures that can be disaggregated into consumption, intermediate, and capital goods tariffs. Importantly, given concerns about the Sachs-Warner and other binary policy measures, we implement tests using both discrete and continuous treatment measures. Finally, we answer the right policy question, attend to inference and identification problems, and avoid biases by using the difference-in-difference approach. In other words we seek a treatment-and-control partition of countries on the basis of whether they engaged in WC-style trade liberalization, and we see whether the liberalizers experienced accelerated growth relative to nonliberalizers.

Using this "policy experiment" approach we perform growth empirics based on identification in the time dimension rather than in cross section. Using similar methods previous authors have used a variety of trade openness indicators, some of them subject to the Rodríguez and Rodrik critiques, and some of the dating from the pre-WC era. Harrison (1996) studied only the pre-WC period using trade liberalization proxies for approximately the 1960s-1980s period, though not all were strict policy measures (e.g., trade shares). In some ways, the closest article to ours in spirit is by Slaughter (2001), but his focus was also pre-WC, dealing with the EEC, EFTA and Kennedy round liberalizations that primarily affected rich countries in the 1960s and 1970s. The study by Dollar and Kraay (2004) encompasses developing countries and runs through the 1990s, but they identified liberalizers using growth in nominal trade shares, an endogenous variable. As Kraay $(2007,139)$ admits, if one is looking for policy prescriptions, then "one can always object" to findings based on trade volumes rather than trade policies. ${ }^{4}$ Turning to recent studies using policy measures, Lee, Ricci and Rigobon (2004) find weaker results using continuous average tariff or duty measures than with trade volumes. Wacziarg and Welch (2008) find positive results, but they use the Sachs-Warner indicator (extended to more recent years), a variable that is disliked by skeptics and which includes some non-trade-policy components.

\footnotetext{
${ }^{4}$ Dollar and Kraay (2004) do find that countries that experienced more rapid trade share growth also experienced sharper tariff declines. But as Rodrik points out in his October 2000 critique of their paper, "The authors combine a policy measure (tariff averages) with an outcome (import/GDP) measure in selecting countries. This is conceptually inappropriate, as policy makers do not directly control the level of trade. Saying that 'participation in world trade is good for a country' is as meaningful as saying that 'upgrading technological capabilities is good for growth' (and equally helpful to policy makers). The tools at the disposal of governments are tariff and non-tariff barriers, not import or export levels." See http://ksghome.harvard.edu/ drodrik/Rodrik\%20on\%20Dollar-Kraay.pdf.
} 
Our approach is somewhat different. First, starting from theory we focus attention on input tariffs, that is, on capital and intermediate goods. Then we painstakingly collect new and more detailed tariff data on consumption, capital, and intermediate goods from primary sources, using easy digital sources for recent years, but with recourse to some extremely cumbersome and hitherto unused archival sources for the 1980s. Based on a difference-in-difference design we then $d o$ find a significant correlation between tariff reductions and growth acceleration in the last 30 years, one that is much stronger for tariffs on capital and intermediate goods than for average tariffs. The estimated impacts are large, but not too large: about 1 percentage point per year higher growth for liberalizers. But this is reassuring, for two reasons: the impacts are plausible and they mesh with the predictions of a simple calibrated model.

In the next section we develop a basic growth model where trade can play a role and use simple calibrations to estimate the plausible magnitude of policy impacts. Drawing on the theory, we then confront the need for more detailed tariff data than have been used to date, and describe how we collected and collated these data from primary and secondary sources. In the final main section, we test the theory using the data by applying statistical methods of the treatment-control type that avoid many of the problems common to cross-section methods. We also address endogeneity concerns using new arguments, since standard instruments are of no use in this context and changes in trade policy are more strongly correlated with changes in growth rates than changes in institutions or schooling. Policy changes also correlate with other changes predicted by theory such as capital goods prices, investment levels, and capital inflows.

\section{Theory and Calibration}

Any reasonable model of the relationship between trade protection and growth must be about more than the static gains, those resulting from the elimination of allocative inefficiencies (i.e., Harberger triangles). In any reasonably calibrated static general-equilibrium model the gains are simply far too small to matter in this debate. For example, a much-cited study of the likely impacts of the Doha round estimated that the static gains for developing countries of completely free trade would amount to just $0.8 \%$ of income (Anderson and Martin 2005, Table 3). The World Bank (2005) stands behind these estimates. As Rodrik $(2006,976)$ puts it:

One of the insights of [the World Bank's] Learning from Reform is that the conventional package of reforms was too obsessed with deadweight-loss triangles and reaping the efficiency gains from eliminating them, and did not pay enough attention to stimulating the dynamic forces that lie behind the growth process. Seeking efficiency gains does not amount to a growth strategy. Although the report does not quite put it in this way, what I think the authors have in mind is that market or government failures that affect accumulation or productivity change are much more costly, and hence are more deserving of policy attention, than distortions that simply affect static resource allocation.

So we must move beyond static CGE analysis and look at dynamics using a growth model. But for a growth model to be useful here it must include some basis for trade. A realistic and simple production system for this purpose is a model of at least two sectors where a developing country 
has a comparative disadvantage in producing (some) inputs to the production process, be they capital inputs (durable for many periods) or intermediate inputs (nondurable). ${ }^{5}$

An early and clear exposition of this sort of model is that of Mazumdar (1996), which was written as a response to Baldwin (1992). The model features consumption and capital goods (but not intermediates), and the goods are produced with identical factor shares, so that HecksherOhlin and Stolper-Samuelson effects are absent. As a result, countries are completely specialized. This assumption of uniform factor intensities is now commonplace. ${ }^{6}$ Using this type of model one can explore both transitional dynamics and the steady state, where the dynamics of factor accumulation can follow either Solow or Ramsey mechanics. ${ }^{7}$

How does trade policy enter these models? Tariffs on imported capital goods lower the steady-state level of output since the tariffs are a tax that distorts the relative price of capital (De Long and Summers 1991; Jones 1994; Taylor 1994, 1998). The developing country, with its comparative disadvantage in producing capital goods, will see the price of capital goods fall when trade is liberalized. In a neoclassical model, this leads to medium-run growth effects (growth speeds up in the transition to the new steady state) and a long-run level effect (the new steady state will have higher GDP, all else equal). We now develop and calibrate a Solow/Ramsey model of this type, with both traded and nontraded inputs, allowing for the inputs to include both capital goods and intermediates. ${ }^{8}$

\section{A Calibrated Model}

We assume a small open "developing" economy (developing here means an importer of capital and intermediates; some rich countries fit this description). Output is used for consumption, as a nontraded intermediate variety, as a nontraded capital variety, or is exported to obtain imports of traded intermediate and capital varieties. Output is made using two factors of production, labor L and capital $\mathrm{K}$. The labor endowment is $\mathrm{L}=1$ fixed; but capital $\mathrm{K}$ can be accumulated.

The production of output $Y$ given factors $K, L$ and intermediate inputs $X$ is

$$
Y=\left(K^{\alpha} L^{1-\alpha}\right)^{1-\sigma} X^{\sigma}
$$

and the Cobb Douglas form means that spending on intermediates $X$ is equal to $\sigma Y$. Thus GDP, or value added, is given by $(1-\sigma) Y$.

Trade is balanced. For simplicity, output is the numeraire, and is exportable with no tax or friction and the world (and domestic) price of this good is set to 1, without loss of generality. Units are chosen so that world prices of the imported goods are also equal to 1 . The imported capital goods have a domestic price $P_{I}$ and imported intermediates have a domestic price $P_{X}$,

\footnotetext{
${ }^{5}$ On North-South trade in capital goods see Eaton and Kortum (2001).

${ }^{6}$ See, for example, Hsieh and Klenow (2007).

${ }^{7}$ Mazumdar (1996) examines both the Solow and Ramsey cases. In the first model of Eaton and Kortum (2001), and in Hsieh and Klenow (2003), the focus is on either Solow or Ramsey steady states.

${ }^{8}$ For a similar argument in an "AK" model see Lee (1995) or Gallup, Sachs, and Mellinger (1999). In these cases, the tariff reduction has permanent effects on the growth rate of income, not its level.
} 
where $P_{I}=\left(1+t_{I}\right)$ and $P_{X}=\left(1+t_{X}\right)$ and the $t_{I}$ and $t_{X}$ are ad valorem tariffs. For simplicity we can assume that other transport costs are zero (or we assume that 1 is the CIF price) but this does not affect the argument.

With regard to technology assumptions, we will look at two extreme cases in order to check the sensitivity of the response of growth to tariffs in this setting. For simplicity we look at cases where there is no change in the traded/nontraded margin, although such effects would magnify the gains from trade and could form the subject of future research.

- Case 1. All I and X goods are traded and can be imported. Domestic output can only be used for consumption or exported. In this case there is $100 \%$ pass through from tariff changes to the domestic input prices of I or X. This will lead to a high estimate of the impact of tariffs on growth and income, although the impacts would be larger if we allowed for gains from changes in the traded/nontraded margin.

- Case 2. A fraction of the I and X goods are imported varieties and the rest are nontraded and have to be produced from domestic output. For simplicity, the traded-nontraded goods are combined in Leontief fashion so that there is no change in the marginal good (the traded/nontraded boundary is fixed). In this case there is only a limited pass through of tariff changes to the domestic price index of I or X goods. This will lead to a low estimate of the impact of tariffs on growth and income.

For each case we look at two types of accumulation dynamics: Solow and Ramsey. Our simulations begin with the economy at its steady state with tariffs in place.

\section{The Solow Version}

In the Solow model spending on inputs is $\sigma Y=P_{X} X$ and on investment is $s(1-\sigma) Y=P_{I} I$, where $s$ is the exogenous savings rate. Consumption of domestic output is the remainder, $(1-s)(1-\sigma) Y$.

Substituting for intermediates $\mathrm{X}$ we find

$Y=\left(\frac{\sigma}{P_{X}}\right)^{\frac{\sigma}{1-\sigma}}\left(K^{\alpha} L^{1-\alpha}\right)$

We see immediately that a fall in $P_{X}$ is isomorphic to a rise in total factor productivity $(A)$. This is one place where reductions in intermediate tariffs create dynamic gains.

Turning to capital goods, the dynamic equation for $\mathrm{K}$ is

$\Delta K=\frac{s(1-\sigma) Y}{P_{I}}-\delta K$

The steady state is when the level of investment equals depreciation so that

$I=\frac{s(1-\sigma) Y}{P_{I}}=\delta K$ 
which implies that

$\frac{s(1-\sigma)}{P_{I}}\left(\frac{\sigma}{P_{X}}\right)^{\frac{\sigma}{1-\sigma}} K^{\alpha}=\delta K$

Hence the steady state level of capital is

$$
K^{*}=\left[\frac{s}{\delta} \frac{(1-\sigma)}{P_{I}}\left(\frac{\sigma}{P_{X}}\right)^{\frac{\sigma}{1-\sigma}}\right]^{\frac{1}{1-\alpha}}
$$

We now see that a fall in $P_{I}$ is isomorphic to a rise in the savings rate $s$. This is where reductions in capital goods tariffs have the potential to create dynamic gains. We can also see how a fall in $P_{X}$ increases the steady state level of capital, through its TFP-like impact on output.

How does trade policy affect the prices of capital and intermediate goods? This depends on the traded and nontraded shares. In Case 1, with all inputs imported, the tariff cut feeds one-forone directly into the domestic price. In the more general Case 2 this is not true, and the assumption of Leontief technology allows us to see how far intermediate input complementarities can amplify these development frictions. ${ }^{9}$

We assume aggregate investment $\mathrm{I}$ is a Leontief composite of traded goods $\mathrm{T}$ and nontraded goods $\mathrm{N}$, with

$$
I=\min \left(\frac{I_{N}}{(1-\beta)}, \frac{I_{T}}{\beta}\right) .
$$

Since domestic output has a price of 1 , and can be used as the nontraded investment good, the price index for one unit of investment is then $(1-\beta)+\beta P_{I}$.

We assume also that aggregate intermediate input is Leontief composite of traded goods $\mathrm{T}$ and nontraded goods $\mathrm{N}$,

$$
X=\min \left(\frac{X_{N}}{(1-\gamma)}, \frac{X_{T}}{\gamma}\right) .
$$

Since domestic output has a price of 1 , and can be used as the nontraded intermediate good, the price index for one unit of intermediate input is then $(1-\gamma)+\gamma P_{X}$.

The analysis goes through as before except that there is less trade and some home output now goes to make the nontraded capital and intermediate goods. Thus,

\footnotetext{
${ }^{9}$ See Kremer (1993), and the more recent and general "weak links" argument in Jones (2008).
} 
$Y=\left(\frac{\sigma}{(1-\gamma)+\gamma P_{X}}\right)^{\frac{\sigma}{1-\sigma}}\left(K^{\alpha} L^{1-\alpha}\right) ; \quad \Delta K=\frac{s(1-\sigma) Y}{\left[(1-\beta)+\beta P_{I}\right]}-\delta K$

and

$K^{*}=\left[\frac{s}{\delta} \frac{(1-\sigma)}{\left[(1-\beta)+\beta P_{I}\right]}\left(\frac{\sigma}{(1-\gamma)+\gamma P_{X}}\right)^{\frac{\sigma}{1-\sigma}}\right]^{\frac{1}{1-\alpha}}$

For calibration purposes we choose parameters representative of developing countries. We set $\alpha=1 / 3$ following Gollin (2002). We assume $s=0.25$ and $\delta=0.06$. Following Jones (2008) we set $\sigma=0.5$, so intermediates have a $50 \%$ share of output; this is more conservative than the 0.7 postulated by Gallup, Sachs and Mellinger (1999). In the case of fully traded inputs we set $\beta=1$ and $\gamma=1$. For the case with some nontraded inputs, we set $\beta=0.3$ and $\gamma=0.15$, which are close to the average values in the developing country dataset we use in the empirical analysis later. ${ }^{10}$

\section{The Ramsey Version}

The Ramsey model is identical to the Solow model except that it replaces a fixed savings ratio $s$ with an endogenous savings ratio. Here, the dynamics for $K$ and $C$ are given by

$$
\Delta K=\frac{s(1-\sigma) Y}{\left[(1-\beta)+\beta P_{I}\right]}-\delta K ; \quad \frac{\Delta C}{C}=\frac{r-\rho}{\theta} .
$$

The consumption equation is $C=(1-s)(1-\sigma) Y$ and from the production function we know

$r=\left(\frac{\sigma}{(1-\gamma)+\gamma P_{X}}\right)^{\frac{\sigma}{1-\sigma}} \frac{\alpha K^{\alpha-1}}{\left[(1-\beta)+\beta P_{I}\right]}$

At the steady state $r=\rho$ (where $\rho$ is the discount rate), which implies that

$\rho=\left(\frac{\sigma}{(1-\gamma)+\gamma P_{X}}\right)^{\frac{\sigma}{1-\sigma}} \frac{\alpha K^{\alpha-1}}{(1-\beta)+\beta P_{I}}$,

and hence

\footnotetext{
${ }^{10}$ To compute these parameters for the average country in our dataset we gather import value data by types of goods from the UN COMTRADE database and then compute each type's share of nominal GDP.
} 
$K^{*}=\left[\frac{\alpha}{\rho\left[(1-\beta)+\beta P_{I}\right]}\left(\frac{\sigma}{(1-\gamma)+\gamma P_{X}}\right)^{\frac{\sigma}{1-\sigma}}\right]^{\frac{1}{1-\alpha}}$

Some important similarities between the Ramsey equation (2) and the Solow equation (1) for $K^{*}$ may be noted. The elasticities of $K^{*}$ with respect to changes in investment and intermediate prices are the same. Thus, with respect to changes in tariffs, the long-run steady state implications of the two models are identical, all else equal.

What will differ are the transitional dynamics. As is well known, for typical calibrations the Ramsey model has a much faster convergence speed than the Solow model, and this is true here. Our calibrated Solow model converges at $4 \%$ per year to steady state, which is at the high end of empirical estimates of convergence speed (see e.g., Mankiw, Romer, and Weil 1992; Dowrick and Rogers 2002). Our calibrated Ramsey model converges about twice as fast, at about $8 \%$ per year, a speed rarely seen in empirical work (Caselli, Esquivel, and Lefort 1996).

\section{Simulations}

For the Solow and Ramsey simulations we compute GDP each year and in the final steady state, starting from an initial steady state with $P_{I}=P_{X}=1.25$ (25\% uniform tariffs) and where the policy change at time $T$ is to remove these tariffs. These tariff changes are again comparable to what we shall see in the data for those countries that pursued liberalization in the Uruguay round. Three types of trade liberalization are considered:

- Eliminate the $25 \%$ I tariff and reduce $P_{I}$ to 1 ("I").

- Eliminate the $25 \% \mathrm{X}$ tariff and reduce $P_{X}$ to 1 ("X").

- Eliminate the $25 \% \mathrm{I}$ and $\mathrm{X}$ tariffs and reduce both $P_{I}$ and $P_{X}$ to 1 ("XI").

Simulations of growth trajectories in the Solow and Ramsey cases without nontraded goods are shown in Figure 1. These simulations show, as expected, that the Ramsey results are the same as the Solow results apart from the faster convergence speeds. Investment tariff reductions (I) have no immediate impact, since they do not raise productivity. But they encourage accumulation. In the long run output rises by $11.5 \%$. In contrast, intermediate tariff reductions $(\mathrm{X})$ have an immediate impact, since they raise productivity right away. They also encourage accumulation, like any other productivity shock. In the long run output rises by $39.4 \%$. Finally, when both tariffs are removed, the effects are compounded and in the long run output rises by $55.6 \%$.

Translated into average impacts we can compute the medium-term growth acceleration effects, which are also shown in Figure 1 for comparison with the empirical results from finite samples. We examine growth accelerations over a 15 year period to conform to our empirical design. As expected, the Ramsey model generates slightly higher growth impacts in the first 15 years after a policy change, due to the faster convergence speed. Overall, the simulation suggest a high estimate for the growth impact of eliminating a $25 \%$ tariff would be an extra 2.5 percentage points of growth per year in this window, or 0.1 percentage points of extra growth per 
$1 \%$ of tariff reduction. We note that a very large share (four fifths) of this effect is felt through the impact of cheaper intermediate goods due to the $\mathrm{X}$ tariff reduction.

Simulations for the model with nontraded goods are shown in Figure 2. These simulations show much smaller impacts (note the vertical scale change) because by assumption there is no pass through from tariff reductions to the prices of nontraded capital and intermediate goods. We have set the traded share of capital goods to $\beta=0.3$ and the traded share of intermediate goods to $\gamma=0.15$, so we can see that to a first approximation the impacts on the steady-state output level of reductions in I and $\mathrm{X}$ tariffs will be reduced by $70 \%$ and $85 \%$ respectively. In fact, for investment tariff reductions (I) output rises by 3.7\%. For intermediate tariff reductions (X) output rises by $5.7 \%$. And when both tariffs are removed, output rises by $9.6 \%$.

The medium-term growth acceleration effects of this model are also shown in Figure 2. These effects are about one fifth as big as those seen in table C. Overall, these simulations suggest a low estimate for the growth impact of a $25 \%$ tariff removal would be about 0.5 percentage points of growth per year in this window, or $0.02 \%$ of extra growth per $1 \%$ of tariff reduction. A large part (2/3) of this effect is felt via the intermediate goods channel.

\section{Summary: From Theory To Empirics}

The above simulations can guide our interpretation of empirical results. They already put in a fresh perspective some of the most-cited work from the trade and growth debate. Static CGE models estimating trivial one-shot gains of $1 \%$ or less would appear to be too pessimistic, since the results fail to take into account the dynamic gains from cheaper capital and intermediate inputs. Our low estimate suggests a level effect of 9.6\%, an order of magnitude bigger than these estimated static gains; and our high estimate of $56 \%$ is almost another order of magnitude bigger still. These larger gains from trade are far from trivial for those developing countries (most of them) which must import key intermediate and capital goods.

In our view, the plausible growth and level effects ought to be somewhere between our high and low estimates. Although many goods are nontraded, we can think of several factors that are not included in our simple model, nor in the empirical work we present below, which could cause a higher growth response: the possibility of more aggressive substitution toward cheaper inputs (not allowed by our Leontief specification); the fixed traded/nontraded margin (which surely moves in reality); and the removal of nontariff barriers (absent in this model but which are also removed during trade reforms). ${ }^{11}$

Thus if even our low-end estimate of growth impacts is around an extra 0.5 percentage points per year for 15 years, we might take the view that estimates above 0.5 and perhaps up to $1.0-1.5$ percentage points per year might be reasonable given these extra factors. In the empirical work that follows we find exactly this kind of impact.

\footnotetext{
${ }^{11}$ Although "obfuscation" may sometimes lead to a rise in NTBs which offset tariff reductions (Kono 2006).
} 


\section{Data}

We compiled, and in some cases hand collected, the following data to test the theory.

Growth rate: The dependent variable is GDP per worker (rgdpch) from the Penn World Table (PWT) database (http://pwt.econ.upenn.edu/; version 6.2). Rates of growth on long periods are calculated in continuous fashion, using differences in log levels divided by years elapsed.

Average Tariffs: Three tariff measures are employed. The first is an average tariff measure, for which we use the mean tariff rate from the Economic Freedom in the World (EFW) 2005 database (http://www.freetheworld.com/; variable: Area 4-A(ii) Data). Data are available every 5 years from 1970 to 2000, plus annually for 2001, 2002, and 2003, and the sample size grows from 77 countries in 1970 to 122 in the year 2000. In our regressions we employ samples of up to 75 countries from this database.

Disaggregated Tariffs: Since theory makes an important distinction between capital, intermediate, and consumption tariffs, we go beyond existing measures and compile data on disaggregated tariffs. We compiled data on disaggregated Most Favored Nation (MFN) applied tariffs for two benchmark eras: "early" or "before" meaning circa 1985 (in practice, between 1985 and 1993), and "late" or "after" meaning circa 2000 (in practice, between 1999 and 2001). Note that these applied tariffs may differ from the ceilings set by the bound rates which are the actual object of negotiation in the GATT/WTO process.

For the late benchmark we rely on pre-compiled tariff data by the UNCTAD's TRAINS (Trade Analysis and Information System). However, for the earliest benchmark, TRAINS only covers 23 countries in our sample. Tariff data for 8 European Union countries are based on TRAINS complemented with EU Tariff Schedules. For the rest of the sample, 18 countries, we had no option but to collect the tariff data by hand, line by line, from national tariff schedules from the 1980s. Tariff data for all Latin American Countries comes from national customs schedules provided by ALADI. For the rest of the sample we used published national tariff schedules available at the Library of Congress (Washington, D.C.). This was a non-trivial exercise and for some countries there were many thousands of tariff lines to be collected.

Finally, unweighted average tariffs were computed for consumption, capital and intermediate goods. The use of an unweighted tariff is important to avoid the criticism that is often leveled in the literature at import-weighted tariffs, namely that they may understate protection when some tariff rates are at or near prohibitive levels (see, e.g., Warner 2003; Rodríguez 2007).

In our regressions we employ samples of up to 47 countries from this more restricted database. Further details of our tariff data are provided in the Appendix.

Other Controls: In the course of our empirical analysis we add some control variables in the growth regressions. We measure institutional quality as legal and property rights according to the Economic Freedom in the World 2005 database (Area 2-AB composite score; where 2-A is an index of judicial independence ("the judiciary is independent and not subject to interference by the government or parties in disputes"); and 2-B is an index of impartial courts ("a trusted legal framework exists for private businesses to challenge the legality of government actions or 
regulation")). As is common in growth regressions (see Easterly 2005), we can also include a measure of human capital, proxied by total years of schooling from Barro and Lee (2000) and a catch-up term, initial income per worker (from PWT) to control for transitional dynamics.

\section{Empirics: Design and Implementation}

In this section we present an empirical design which differs from the previous cross-section literature, but which is - we think - better suited to the policy question at hand. In this design, we consider post-1990 trade liberalization as a treatment. We implement the design using two different methods. The first method treats openness as a discrete (zero-one) treatment in the spirit of Sachs and Warner (1995), and uses a difference-in-difference estimator. The second method treats openness as a continuous treatment, following most of the literature, using tariff rates as a proxy for openness in a regression in differences. Difference estimators avoid omitted-variable problems that plague cross-section analysis, at least when the omitted regressors are timeinvariant country characteristics. But the treatment variable must be exogenous. In a later section we consider endogeneity issues and potential instrumental variables.

\section{Empirical Design and The Great Liberalization}

In the older literature critiqued by Rodríguez and Rodrik (2001) the dominant question was: do liberalized countries grow faster than nonliberalized countries, in a given period, all else equal? But this is, we believe, the wrong question. At the very least, it is probably an empirically unanswerable question, since ensuring that all the proper controls are included is likely an impossible task. Thus, the results in this literature are fraught with omitted variable bias, and their resulting fragility, as noted by Rodríguez and Rodrik (2001), leaves little hope of a definitive conclusion - save the meager refuge offered by a null hypothesis of no effect.

In contrast, we think the right question is: does the rate of growth accelerate more in a liberalizing (treatment group) country as compared to nonliberalizing (control group) country? This way of looking at the question has numerous benefits. It corresponds most closely to the policy question being asked by developing country governments before liberalizing, and it also corresponds most closely to the Washington Consensus claim that liberalizers would grow faster then they would have without liberalization-notwithstanding the fact that many other factors, some unobservable, and many unalterable, could still intervene to cause differences in growth rates between countries whether they were liberalizing or not.

This way of looking at the question also leads to a cleaner empirical design, as was noted from the start (Harrison 1996). It naturally leads to an estimation of growth rates in differences, which is immune from omitted variable bias arising from time-invariant characteristics; all country-specific fixed effects in the growth equation are swept away by differencing. A naïve difference equation with no controls could then be perfectly satisfactory, provided the parallel trends assumption is met. More generally, we may have to worry about any variables that change 
over time in the growth equation. However, as in the cross section literature, we know that endogenous variables should not be included as regressors. The variables to be included should be either (a) exogenous or (b) endogenous and properly instrumented. And of course this requirement applies to our treatment variable as much as any other control.

However, studying trade liberalization as a treatment-control problem also raises the stakes empirically. Put simply, if an experimental design is going to work then there has to be some sort of experiment: enough countries need to receive the liberalization "treatment" in sample; enough time needs to elapse so that growth can be observed in both pre- and post-treatment phases; and growth then has to be compared to a control group of nonliberalizers.

And here is the problem: before the Uruguay round very few developing countries had engaged in any serious trade liberalizations. Some had begun the process of trade reform (the NICs and Chile, for example). But for the most part it was the developed countries that had been the main participants in earlier GATT rounds, or in other serious regional trade agreements (notably the EU), that had fostered lower tariffs. For example, the GATT's Kennedy round of 1962-67 included only 48 countries. And although the Tokyo round of 1973-79 included roughly 100 countries, including 20 non-GATT developing countries, the progress made in reducing developing country trade barriers was negligible.

In contrast, the Uruguay round 1986-94 included 125 countries and focused strongly on tariff reductions in both developed and developing countries. This, we would argue, is the experiment that we have been waiting for. Figure 3(a) sums up what the Uruguay round achieved for the reductions in average tariff levels (EFW data). To show what happened we plot post-Uruguay (year 2000) tariffs against pre-Uruguay (year 1985) tariffs. And we divide the world (i.e., our sample) into two groups of countries as follows:

Nonliberalizers: This group of countries did not (or could not) lower tariffs. Hence, there are really two sets of countries hiding with this group.

The first set inherited low tariffs and left them low. These countries are close to the origin in Figure 3(a) and they are countries that never received the treatment because they have always been open. For example, in 1985, a very open economy like Singapore had tariffs as low as $2.2 \%$, which obviously left very little room for further substantive tariff reductions after 1970. (Tariffs in Singapore fell to zero in 2000.) Clearly, the trade policy element of the Washington Consensus did not speak to this group of countries: they had practically converged to free trade before the Uruguay round and without any nagging from the Beltway. Thus, no growth accelerations induced by trade policy could be expected in these early liberalizers after 1985.

A second set of countries inherited high tariffs and left them alone, or even raised them. These countries are close to the diagonal on the upper right of Figure 3(a) and they are countries that never received the treatment because they have always been closed. For example, Jordan had an average tariff of $13.8 \%$ in 1985 and $24 \%$ in 2000, according to EFW. Jamaica's measured tariff fell from $17 \%$ in 1985 to just $10.6 \%$ in 1999; a cut in 
tariffs, but not a big one. Clearly, the Washington Consensus potentially could have spoken to these countries, only they did not pay much attention to it.

Liberalizers: In contrast, a third and final group of countries both could and did lower tariffs after 1985. They had large tariffs to begin with and cut them. These countries are below the diagonal on the lower right of Figure 3(a) and they are countries that received the treatment because they made a big move from being closed towards being open. They are selected as countries with an above median decrease in tariffs between 1985 and 2000. For example, Argentina had average tariffs of 27\% in 1985, falling to $12.6 \%$ in 2000 . This group also includes some developed countries: for example, Australia and New Zealand, who also embarked on trade liberalization in the 1980s and 1990s (but they are example of rich countries that also are net importers of capital and intermediate goods, so they also fit the rubric of our model).

Another classic example would be India with tariffs as high as $98.8 \%$ in 1985, falling to $32.5 \%$ in 1999 - still high, but a whole lot lower than before. It is obviously to this third group of countries that the Washington Consensus spoke. Their pre-WC trade policies placed an enormous "tax" on imports (including imports of capital and intermediate goods) that was subsequently removed. In fact, the true extent of liberalization was probably much larger than shown here, given the way the tariff data were sampled and our inability to measure changes in nontariff barriers. ${ }^{12}$ The question is, following this liberalization, did this treatment group see any pay offs in terms of improved growth performance?

Figure 3(a) shows that we have suitable control groups and treatment groups for the proposed experimental design. Figure 3(b) replicates the approach using our more restricted sample of capital and intermediate goods tariffs from our newly collected disaggregated tariff data. Again, we can partition the sample to isolate the "off diagonal" countries that embraced the Washington Consensus, and those on the diagonal which did not liberalize.

To further describe the evolution of tariffs in these samples, Figure 4 plots the average tariffs for different subsets of countries from 1975 to 2000 using EFW average tariff data. Figure 4(a) shows averages for the whole sample, developed countries and developing countries. The developed world started with lower tariffs and lowered them a little (about $10 \%$ falling to about

\footnotetext{
${ }^{12}$ Our tariff variable probably measures the "lower bound" on tariffs in the early period and the "upper bound" tariff in the late period. Early tariffs are mostly measured near the end of the period (the late 1980s) and tariffs were probably much higher in the mid 1970s (in many countries the difference would probably be small). Similarly, our late tariffs exclude further tariff declines for selected trading partners that resulted from the explosive growth of preferential bilateral and regional free-trade agreements (FTAs). The difference here could be more substantial in some cases. Still, although preferential/regional agreements are seen by some as inimical to the GATT/WTO process (Bhagwati 2008), and perhaps also contrary to the spirit of the Washington Consensus, empirical evidence suggest that there are substantial spillovers from FTA tariff reductions to subsequent unilateral (ex-WTO) MFN tariff reductions. According to Estevadeordal, Freund, and Ornelas (2008), a country that provides preferential tariff-free access in a sector with a $15 \%$ MFN tariff is then likely to subsequently lower its MFN tariff by 3 percentage points, suggesting that the WTO mechanism encourages countries to set MFN rates close to prevailing applied rates.
} 
$5 \%$ ), but that the developing world lowered tariffs more dramatically in the 1980s and 1990s (about $35 \%$ falling to about $15 \%$ ).

Figure 4(b) shows average tariffs for the two aforementioned groups. The nonliberalizers saw very little movement in their average tariff rate: it stayed about $15 \%$ to $20 \%$ throughout. The control group thus saw very little tariff change from 1975 to 2000. The really dramatic change is seen in the treatment group, the liberalizers: initially in 1975, 1980, and 1985 their average tariff rates exceeded $40 \%$. But in the WC-era, after the Uruguay round, these countries cut average tariffs to a much lower level, around 15\%, a cut of about 25 percentage points (similar to the cut used in our earlier model simulations). Exploiting this contrast between liberalizers and nonliberalizers should allow us to identify any pro-growth impacts of trade liberalization.

\section{Openness as a Discrete Treatment: Difference in Difference Estimates}

We begin our empirical work using the simplest notion of treatment, a dichotomous variable to capture those countries thought to have liberalized (Liberalizer=1) versus those that have not (Liberalizer=0), using the definitions of the previous section. This approach is the differenceregression analog of the zero-one openness indicator used by Sachs and Warner (1995) and their followers. Thus, if we suppose the levels regression is written

$$
\text { growth }_{i}=\alpha\left[\text { openness }_{i}\right]+\beta X_{i}+\varepsilon_{i},
$$

where $\mathrm{X}$ is a vector of control variables, then the differenced regression can be written

$$
\Delta \text { growth }_{i}=\alpha\left[\text { openness }_{i}\right]+\beta \Delta X_{i}+v_{i}
$$

By replacing sopenness $_{i}$ with our indicator variable "Liberalizer" we hope to capture those countries which, in the WC-era, shifted to a more liberal trade regime.

The resulting difference-in-difference (DD) regressions offer a very clean and simple test of the hypothesis that WC-era liberalizers grew faster than nonliberalizers using data from reasonable sample periods. In our work, there are two periods $(T=2)$. Period 1 is 1975 to 1989 and period 2 is 1990 to 2005 . By splitting the sample into two 15 year periods we can hope to avoid any pollution of our conclusions as a result of lags in policy implementation and short-run output fluctuations (e.g., business cycles, crises), and yet the time frame is sufficiently short that (as our simulations have shown) we should still be able to detect medium-term post-reform growth accelerations. Using two periods is also justified by data limitations since we only have one pre-reform observation on tariff rates. Finally, restricting analysis to two periods "before" and "after" treatment may be a blessing in disguise, since DD methods with $T>2$ run the risk of biased standard errors (Bertrand, Duflo, and Mullainathan 2004).

In asking whether trade reform episodes were followed by increased growth rates, our method is also close in spirit to the study of growth accelerations by Hausmann, Pritchett, and Rodrik (2005). We are able to employ more recent data (they use PWT 6.1, but PWT 6.2 adds 4 extra years). We also differ in using 15-year periods for this analysis, as growth rates over 
quinquennia are likely to be volatile and beyond the explanatory powers of a medium run growth model (Easterly et al. 1993). The longer time-horizon is also a harsher test: worthwhile policy recommendations need to generate enhanced growth performance over many years, not a flash in the pan. Like these authors we find that sustained growth accelerations are correlated with economic reforms, although our focus is on trade policy - and a continuous measure, as opposed to the discrete Sachs-Warner indicator variable used by Hausmann, Pritchett, and Rodrik (2005).

Table 1(a) reports the results of these difference regressions. The dependent variable is the annual average growth rate of per worker GDP from the Penn World Tables, version 6.2. This first set of regressions in columns 1 to 6 include no control variables other than "Liberalizer", but "Liberalizer" is defined in various ways. The first definition in column 1 sets Liberalizer $=1$ for countries where the average tariff rate falls by more than the median for the entire sample between period 1 and period $2(N=75)$. Other definitions in columns 3-6 are like the first, except that the tariff on consumption goods, capital goods, intermediate goods, or the average of capital/intermediate goods is used, based on our disaggregated tariff data for a smaller set of countries $(N=47)$.

Will the use of different tariff measures matter? One might worry that the results could be similar whatever tariff measure is used, making our pursuit of disaggregated tariff data rather pointless, since the average tariff would be information enough. Why? Although the measures involving capital and/or intermediate goods tariffs should be the better measures of the growthenhancing effects of trade policy according to our theory, in practice countries tended to lower tariffs of all kinds simultaneously during trade reforms. To examine this problem we can look at the correlations between the different discrete liberalization indicators. The correlation between the liberalization indicator using average tariffs and that using consumption tariffs was 0.66; the correlation between the liberalization indicator using average tariffs and that using capital and intermediate tariffs was only 0.57. Clearly, countries did tend to lower all tariffs together, but the fact that these correlations are much less than 1 shows that the information contained in average tariffs may be polluted by different shifts in consumption tariffs, an element of noise that would pollute the tariff-growth correlation if our theory is any guide.

This caution turns out to be justified. Table 1(a) offers support for the Washington Consensus prescription, but it does depend on the tariff measure used. Liberalizing countries grew about 1 percentage point per annum faster than nonliberalizers in this period. The effect varies slightly between about $0.85 \%$ and $1.14 \%$ depending on the indicator employed, but the effect is found to be slightly more significant when the theoretically "correct" capital tariff data are used, whereupon the effect then clears the $5 \%$ statistical significance hurdle.

Table 1(b), columns 1 through 6 repeat the exercise with the inclusion of widely used control variables from the growth literature. Following the state of the art, standard reduced-form estimates of a growth regression should include only those few controls $X$ that are putatively exogenous, such as initial income (log), initial schooling, and initial institutions (Barro 1991). Clearly endogenous variables such as investment or trade flows must be omitted from the right hand side. Putting the three controls into difference form implies that $X$ should contain the 
lagged level of growth, the change in schooling and the change in institutions. These are now added to the Table 1(a) difference regressions. Schooling is total years of schooling (variable: tyr) from Barro and Lee (2000). Institutional quality is measured by the EFW legal and property rights score (variable: area $2 \mathrm{ab}$ ).

As Table 1(b) shows, the inclusion of these controls neither dramatically strengthens nor weakens the previous results. Columns 1 through 6 show that the liberalization indicator coefficient still enters significantly at the 5\% level in columns 3-6. The size of the liberalization effect is slightly muted, but still about $0.9 \%$ per annum in columns $3-6$.

The coefficient on the lagged growth variable corresponds to the convergence speed, and since time is measured in 15-year periods, a coefficient of about 0.53 in Columns 3-6 implies an annual convergence speed of almost $4 \%$ in log levels. These are not unreasonable convergence speeds, certainly compared to the empirical literature and the Solow model (the typical Ramsey model calibration implies higher convergence speeds, however). Schooling is not statistically significant in any regression. Institutional change is weakly significant only in column 1 at the $10 \%$ level.

This finally leads us to our preferred OLS specifications in Table 1(c), which exclude the not significant institutions and schooling variables. In this final table, the results line up very closely with our a priori expectations. Using the crude average tariff variable produces a smaller and insignificant coefficient on tariffs, which might explain the often weak and non-robust results in the prior literature. Switching to disaggregated tariffs results in a larger and statistically significant coefficient on tariffs (at the 5\% level). In the final column of the table, where the combined capital and intermediate tariffs are used, the coefficient is at its largest, implying a 1 percentage point per annum growth acceleration for liberalizers, and the effect is now significant even at the $1 \%$ level. Table 1(d) shows that identical coefficients are obtained when the sample is restricted to developing countries, although precision inevitably suffers when the sample is cut by about a third.

These results warrant a few further comments. Our empirics have also surmounted another hurdle, for as Easterly $(2005,1056)$ had shown, many earlier results in openness-growth literature proved not to be robust to the inclusion of the catch-up term (here in a differenced form). The failure of Easterly's regressions to be robust may not be too surprising, however, given that (for survey purposes) he follows the extant literature in using trade share as a measure of openness - when, of course, this is an inappropriate outcome variable rather than a direct measure of policy. We also find, in contrast to the levels results discussed by Easterly, that our growth results are robust to the inclusion of institutional controls, which is not too surprising since institutions change very little in the short to medium run. Likewise, changes in schooling policies seem to be either too small to matter or otherwise uncorrelated with acceleration outcomes. We would also argue that, in the face of Easterly's warning about the "arbitrary" measures of episodes of policy change (he refers explicitly to Sachs and Warner 1995), we have found a very direct measure of trade policy change by looking directly to the changes in trade taxes, rather than inferring reform events based on an amalgam of aggregated tariff data, black 
market premia, government monopoly measures and so on (Easterly 2005, 1050). Our tariff variable may be narrow, but it is cleanly defined and measured.

\section{Openness as a Continuous Treatment: Difference Estimates}

We do not dwell further on the results from Table 1, since, like the Sachs-Warner openness measure, our use of a dichotomous liberalization treatment indicator can be faulted by skeptics for throwing away too much information by reducing a variety of policy stances to an on-off dummy variable. In what follows we maintain our basic empirical design based on differencing, but now we make use of the fact that changes in tariffs provide a continuous treatment measure, and so we switch to using difference regression with a continuous variable, the change in $\ln (1+$ tariff $)$, replacing the liberalization indicator variable as the measure of policy change.

Echoing Table 1(a), Table 2(a) now reports results using the continuous treatment measure $\log (1+$ tariff $)$ and, for now, no other controls, where the tariff measure is again constructed in various ways: for average tariffs (weighted, from EFW), and for tariffs (unweighted, based on our own work), where the latter is computed for consumption, capital, intermediates, and an average of capital and intermediates.

In column 1, using average tariffs, we find a tariff-growth coefficient or elasticity of -0.0519 , which is in line with the lower end of our theory-based calibration estimates. With the inappropriate consumption tariffs in column 2, this coefficient falls to -0.0222 and is significant only at the $10 \%$ level. But when we use capital and/or intermediate tariffs in columns 3 to 5 the coefficient is much larger. The average capital/intermediate tariff level yields a tariff-growth elasticity of -0.0407 in column 5 , and clears the $5 \%$ significance level.

Following Table 1(b), Table 2(b) now reports results using the continuous treatment measure $\log (1+$ tariff $)$ but with additional controls comprising lagged growth, change in schooling and change in institutions. Compared to the results without controls in Table 2(a), the tariff coefficients are now reduced in magnitude and statistical significance, but the same patterns hold, in that the inclusion of the consumption tariff clearly biases the coefficient toward zero.

However, yet again the only control variable that consistently enters with statistical significance is, once more, the catch up term using lagged growth. Again, neither institutional change nor changes in schooling appear to drive growth accelerations across these two periods at conventional significance levels. The catch up coefficient takes values in the range from -0.5 to -0.6 , so implied convergence speeds are again a reasonable $3 \%-4 \%$ per annum.

Once more, following Table 1(c), we again turn in Table 2(c) to a parsimonious specification that excludes the insignificant institution and schooling variables and constitutes our preferred set of OLS results for the continuous treatment case. Again, the same patterns hold. Using average tariffs or consumption tariffs muddies the waters in columns 1 and 2: the tariff coefficient is smaller than one might expect (about -0.2) and not robustly significant. In columns 3 through 5 the coefficient is larger, of a theoretically more plausible magnitude $(-0.4)$, and statistically significant at the $5 \%$ level. Table 2(d) yet again shows that identical coefficients are obtained when the sample is restricted to developing countries, although precision again suffers. 
To sum up, the main lesson is that growth gains of a reasonable size are detectable using theoretically grounded tariff rates for capital and intermediate goods, but using the wrong tariff measures can lead to an understatement of those gains, and bias findings towards a null effect.

\section{Endogenous Treatment?}

One reservation skeptical readers may harbor is that our coefficient on the tariff measure may be subject to endogeneity bias. If institutions "rule" then tariff policy is just a symptom, not a cause, of better economic performance. This kind of relationship is often summed up in causal diagrams in the following way:

$$
\begin{aligned}
& \text { Institutions } \\
& \text { (political or economic) }
\end{aligned} \Rightarrow \begin{aligned}
& \text { Policies } \\
& \text { (trade and other) }
\end{aligned} \quad \Rightarrow \begin{aligned}
& \text { Growth } \\
& \text { (or steady state income) }
\end{aligned}
$$

Such diagrams may also be augmented by other causal arrows and other factors, such as geography (see for example similar diagrams in Acemoglu, Johnson, and Robinson 2001; or Rodrik, Subramanian, and Trebbi 2004).

Based on this kind of causal logic and new empirical work, the "institutions view" has supplanted the "policy view" in recent years. But if the effect we have measured is robust, then this shift may be premature, or may stem from a false dichotomy. The above causal relationship (3) may find support in levels (cross section), but it does not find support in differences (time series). As we show in this section, there is no clear and robust relationship between institutional changes and trade policy changes in our sample, so it is hard to argue that fixing one trumps fixing the other: countries with "bad" (or worsening) institutions have managed to engage in trade reform; countries with "good" (or improving) institutions have also failed.

We therefore seek to construct better instruments for trade policy changes, based on different historical reasoning. Our new instruments fare much better and they support the findings from the previous section. Indeed, they strengthen the findings, since the use of instrumental variable (IV) estimation has the added benefit of addressing problems of measurement error, which can be serious when using tariffs as a measure of liberalization (e.g., given the problem of unmeasured changes in quotas and other nontariff barriers).

\section{Endogeneity, Round 1: Institutions as "Deep Determinants"}

The recent literature has argued that "institutions" are key determinants of income levels (Acemoglu, Johnson, and Robinson 2001). The difficulty is that good institutions may cause higher income but there may also be reverse causality as in (3). The same may also be true of other proximate determinants of growth, such as policies. To escape, researchers have had to find creative sources of exogenous variation-and creative chains of causation - to perform IV estimation. Thus settler mortality long ago is now a popular instrument for the quality of 
institutions today (Acemoglu, Johnson, and Robinson 2001); another widely used instrument is legal origin (Glaeser et al. 2004). ${ }^{13}$

These ideas have certainly advanced the rigor of levels accounting. But the problem for us is these causal chains and instruments are not relevant once we change the experimental model to a difference estimator for medium-term growth accounting. First, consider the instruments. Suppose (lagged) settler mortality predicts institutional quality in 1985 in levels; it does so for 2000 also. But taking first differences we would find (to a first approximation) that the change in institutions (one of our regressors) is a function of the change in (lagged) settler mortality. But there is likely no change in lagged settler mortality, and certainly none in the available pre- $19^{\text {th }}$ century data; even if there were, we suspect it would not provide a plausible theory of institutional change over the 15-year period from 1985 to 2000 . The same problem would arise more starkly if we switched to say, legal origin, as the preferred instrument: legal origins don't change so differencing them isn't an option. Similar problems apply to latitude, disease environment, other geography variables, religion, and so on. To sum up, time invariant "deep determinants" are useful for levels analysis, but inappropriate for growth analysis using difference estimators.

The absence or irrelevance of deep determinants is troubling, but we should recall that the main concern about our pro-WC results in Tables 1 and 2 is that changes in trade policy might be endogenous and really just a proxy for improved institutions. If so, the Rodrik-SubramanianTrebbi (2004) critique would bite and the non-significance of our institutional change variables would just be the result of misspecification. We now show that, even absent instruments, we can find little prima facie evidence that changes in institutions might really be driving everything.

Table 3 shows that institutions measured in levels might have affected trade policies measured in levels. But the same is not true for differences. We focus panel (a) with the full sample. In columns 1 and 4, the level of tariffs in 1985 as measured by $\ln (1+$ tariff), is regressed on the levels of "institutions" in two ways: first, using our previous measure of economic institutions, in this case institutions-as-protection (EFW legal \& property rights index); and then using a "deeper" measure of political institutions, or institutions-as-democracy (Freedom House political liberty index). The levels relationship is strong at the $1 \%$ significance level, and it is consistent with the standard story in the above ordering: countries with "better institutions" had lower tariffs. The relationship also survives in a more restricted developing-country sample in Panel (b), but only for the EFW measure.

But for assessing the causes of policy change we care about changes in tariffs. Columns 2 and 5 regress changes in tariffs (our variable of interest) on levels of institutions. The relationship is only significant in the latter case, and in both cases it has a perverse positive sign. Better initial institutions were associated with smaller tariff reductions. However, if the widely used causal ordering (3) is correct, it should hold in differences too, and then we shouldn't really

\footnotetext{
${ }^{13}$ To enter institutions into a horse race with trade volumes, settler mortality as an IV has been joined up with distance as an IV, the latter being standard instrument for trade volume in the gravity framework (Rodrik, Subramanian, and Trebbi 2004).
} 
regress changes on levels. Differencing both sides would lead us to regress changes in tariffs on changes in institutions. If this yielded a robust association then one might conjecture that the Washington Consensus tariff reforms were nothing but a symptom of deeper institutional changes that were-directly or indirectly-the main reason for accelerating growth rates. Unfortunately, we find no support for that conjecture. Columns 3 and 6 show that institutional changes were not correlated with changes in tariffs in the manner suggested by a causal ordering such as (3). In both panels (a) and (b) the coefficients are statistically insignificant.

There is absolutely no stable or predictable relationship between levels or changes in institutions and changes in tariff policy. Perhaps this is not too surprising. The failure to find a change-change relationship could have been anticipated: during the Great Liberalization, as we have seen, tariff policies changed dramatically in many countries, but it is well known that institutions, in contrast, are highly persistent.

The failure to find a level-change relationship could also have been anticipated. It is a truism of contemporary political economy that we see trade reforms in a variety of institutional environments; under regimes with good and bad governance; under dictatorships and democracies. The regressions are telling us that when the Great Liberalization experiment happened in the treatment group it was not a biased sample of countries in terms of either the level or trend of institutional quality.

\section{Endogeneity, Round 2: The Great Depression, GATT, and Reglobalization}

Now we look in new directions for exogenous variation in 1980s and 1990s trade policy, since contemporary changes in institutions seem to have been mostly irrelevant.

Instead, we take the view that the main exogenous shock to trade policy in the last 100 years was the period of the so-called Great Reversal, from 1914 to 1945. Wars damaged trade but even more damage was done by policy reactions during and after the Great Depression (Kindleberger 1989; Estevadeordal, Frantz, and Taylor 2003; Glick and Taylor forthcoming). Policies were mediated via a multitude of political economy channels leading to a persistent protectionist environment after 1945 that was a far cry from the liberal world order of 1913. Tariffs were much higher than in 1913 in most places, and whilst almost nobody had seen NTBs (quotas) in 1913 they were in widespread use by 1945.

Into this autarkic scene came the postwar international organization charged with rebuilding a broken world trading system: the General Agreement on Tariffs and Trade (GATT) created in 1947, and succeeded much later, in 1995, by the World Trade Organization (WTO). GATT organized multiple rounds of multilateral bargaining to reduce tariffs among member states. In order to achieve tariff reductions under GATT, countries had to engage in a negotiation game where they exchanged proposed lists of tariff cuts with partners; if such cuts were then agreed, they were extended to all parties via the "most favored nation" (MFN) mechanism. But with most developing countries not taking any serious part in GATT until the Uruguay Round, and with very few of them engaging in major unilateral trade liberalization that was robust and enduring (the exceptions being the East Asian NICs), the majority entered the Uruguay Round 
with tariff levels that could be traced back through a history of domestic postwar policymaking to the great shifts in trade policies in the 1930s.

How can we use this set of historical disturbances to the global economy to address the possible endogeneity of our liberalization treatment variables? We argue that a useful causal ordering from which we can extract an exogenous component for the speed and extent of tariff reforms in the 1980s and 1990s is as follows:

$\begin{array}{lllc}\text { Less } & \begin{array}{l}\text { Less intensity/ } \\ \text { persistence }\end{array} & \begin{array}{l}\text { Greater } \\ \text { reductions }\end{array} & \begin{array}{l}\text { Greater } \\ \text { acceleration }\end{array} \\ \text { Great Depression } & \Rightarrow \text { of protection } & \Rightarrow \text { in tariffs } & \Rightarrow \text { in growth from } \\ \text { in the } & \text { under postwar } & \text { in the } & 1975-90 \text { to } \\ 1930 \mathrm{~s} & \text { political economy } & \text { Uruguay Round } & 1990-2005\end{array}$

In essence we argue that the world was disturbed by the interwar shocks in such a way that all countries moved away from liberal economic policies. But how far and how long they did so was, in part, decided by how much of an adverse shock they suffered in the Great Depression. We now explain and defend this identification strategy, and show how we construct two instruments called "GATT Potential" which are good candidate predictors of both the ability and willingness of countries to lower tariffs in the Uruguay round.

The first GATT Potential variable is defined as the interaction of an indicator of GATT membership in 1975 with the pre-Uruguay Round tariff level. These two factors were likely to promote tariff reduction, given the politics and mechanics of trade negotiations under GATT. To see a big tariff cut, a country had to have high tariffs to be able to offer to cut them by a large amount (tariffs cannot be negative); a country also had to enter the Uruguay round with a strong willingness to cut tariffs (which we proxy by 1975 GATT membership). In essence the construction of this variable focuses on the second arrow in the above causal ordering (4), using the decision on countries to enter GATT earlier as indicative of their supposedly historicallydetermined inclination to liberalize.

Still, one problem with this instrument is that we might ask: why were countries willing to enter GATT by 1975 and then cut tariffs in the Uruguay round? The two decisions were likely to be correlated, and so our first variable may not be a valid instrument, as the exclusion restriction might fail. Perhaps some countries knew in 1975 that good trade-related growth opportunities had opened up? In that case we might need a deeper, historical determinant of attitudes to trade reform, which exploits the first causal arrow in the ordering (4). Here we rely on arguments from the political-economy literature-concerning the long-lasting effects of the Great Depression on 
policymakers - that are familiar, but which have been rarely used as sources of exogenous variation in contemporary economic policies. ${ }^{14}$

Writing in mid-century, Polanyi (1944) argued that the Great Depression marked a turn away from the market and a return to a "natural" state of the world in which markets were embedded in a social order. In Polanyi's view, the liberal, laissez faire era of the long nineteenth century was an historical aberration, and the freewheeling globalization it spawned was not sustainable in the long run as a political-economic equilibrium. The interwar crisis was the breaking point. However, if Polanyi and those sympathetic to his view expected the extreme autarky of the 1930s and 1940s to persist, they were to be disappointed.

From the 1950s to the 1970s the global economy was gradually rebuilt under international co-operation, under the auspices of the OECD, GATT, IMF, IBRD, EEC, and a host of other acronyms. Still, this new construct was not necessarily the same as a return to the supposed laissez faire of the pre-1914 years. Trade barriers were only dismantled slowly. An influential characterization of the postwar era is that of Ruggie (1982) who argues that the persistence of post-war trade protection was part of a broader social contract, an "embedded liberalism" where the market economy sat within a managed system that allowed policymakers to contain what they saw as the adverse distributional impacts and volatility created by unfettered free markets.

Moving forward in time, however, as noted by Rodrik (2000), this embedding seems to have weakened considerably as the next great globalization, or reglobalization, unfolded in the 1980s, 1990 s, and 2000s. For some, this recent trend suggest a reversion towards a $19^{\text {th }}$ century free trading world, which would permit us to characterize the long sweep of the $20^{\text {th }}$ century as a liberal order in 1900, followed by a massive deglobalization shock that took the system toward protectionism, and which then slowly unwound as, at their own different speeds, countries gradually relaxed their autarkic stance and re-embraced a more open posture in $2000 .{ }^{15}$

However, this crude description of a "temporary" deviation from laissez faire hides many details. What determined the action and re-action? Why did the speeds vary? What had been the impetus for that sea change in economic thinking, given the orthodox free trade views handed down by posterity through the long nineteenth century and up to the 1920s?

The conventional answer is: The Great Depression; the crisis of world capitalism generated a political economy response. However, if this argument is valid, we would not expect it to create an identical response in all countries, and we ought to be able to find enduring legacies of the Great Depression in subsequent postwar policy choices. Specifically, we test this "Great Depression Hypothesis" to see if the depth of the 1930s downturn can serve as a predictor of slow trade liberalization later on, as in the causal ordering (4) above. Why? Given the account of

\footnotetext{
${ }^{14}$ An illuminating exception is Siegler and van Gaasbeck (2005), who find a cross-country correlation between the depth of the output trough during the 1930s Great Depression and the weight placed on output in a standard monetary policy Taylor rule in the Great Inflation of the 1970s.

${ }^{15}$ Was Polanyi wrong? "It's too soon to tell" is a tempting response, but on the $20^{\text {th }}$ century timescale the predictions look poor. Prior to the $19^{\text {th }}$ century the role of the market is also hotly disputed, with some historians seeing a dominant role for mostly free markets back to the medieval period. See for example the arguments of Greg Clark and Fred Block at http://economistsview.typepad.com/economistsview/2008/06/polanyis-the-gr.html .
} 
history by Polanyi, Ruggie, Rodrik (and many others), we would expect the embrace of globalization by developing countries not to be uniform, but to be conditioned by their own history - with attitudes towards free trade ultimately mediated by politics, the power of interest groups, the persistence of beliefs, and so on.

Thus our second GATT Potential instrument is calculated as the interaction of Great Depression intensity with our initial period tariff level. Since 1930s growth experience was far removed from 1980s and 1990s growth experience, and related to many factors specific to that era such as terms of trade shocks in the commodity lottery and the collapse of the gold standard, we have good a priori reason to believe that the exclusion restriction will be valid and there will be no direct impact of 1930s experiences on growth accelerations circa 1990.

So we can construct two instruments as follows for each country, which we think should be strong instruments for potential for tariff reductions under the Uruguay round of GATT between 1985 and 2000, the early and late periods in our study:

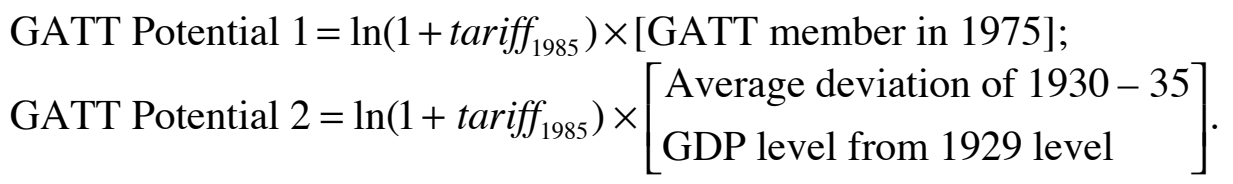

The former uses the Rose (2004) database for GATT membership dates. The latter uses the Maddison (2001) database for historical GDP data.

Reassuringly, our findings are robust when we switch use these measures of GATT Potential as an instrument, and Tables 4 and 5 report IV estimates of our differenced growth regression using each of these two instruments.

On a priori grounds we thought that our GATT potential variables ought to be correlated with tariff cuts, and they are. Figure 5 shows the strong bivariate correlation between the instruments and the change in tariffs. Column 1 in each table shows the coefficient and standard errors on the instrument in the first-stage regression where the dependent variable is the change in capital and intermediate tariffs. The t-statistics are high, around 7 or 8 . If we are willing to accept that the instruments are valid, then they are certainly not weak.

Column 2 in each table presents the IV estimates of the second-stage differenced growth regression on the full sample. The coefficient on tariffs is similar to and never more than slightly larger than the OLS coefficients in Table 4, suggesting that bias problems are not severe. Most importantly the IV coefficients are significant at the 5\% level, even in the restricted sample using disaggregated tariffs. As a robustness check, in Columns 3 and 4 of each table we add schooling and institutions variables and the results are unaffected, with the tariff-growth elasticity still estimated at about -0.05 and significant at the $5 \%$ level. Identical coefficients obtain from regressions restricted to the developing country sample (not shown), but with lower precision. ${ }^{16}$

\footnotetext{
16 Precision suffers especially when we use the Great Depression instrument, because we only have N=16 developing country observations in the Maddison GDP database for the period 1929 to 1935.
} 


\section{Corroborations}

This study has focused on the reduced-form relationship between trade liberalization and growth implied by a simple two-sector open economy growth model. We have seen that empirical evidence from the post-Uruguay Round "Great Liberalization" experiment offers support for the model. Liberalizers grew faster than nonliberalizers. But is this finding fully persuasive?

Easterly (2005) warns that evidence of this sort should be carefully scrutinized to ensure that all of the structural linkages suggested by theory are also verified in the data, otherwise the correlation of policy change and growth may be spurious. To that end, Table 6 examines some correlated variables that we would expect to see change given the purported liberalizationgrowth mechanism. It is, by now, unnecessary to explain that we view all of these variables through the difference-in-difference framework: we examine the before-and-after levels in liberalizers and nonliberalizers (based on the full sample with average tariffs) and look for the right direction of change.

Panel (a) looks at the PWT price index for investment goods. If the theory is correct then capital importers who liberalize should see the domestic price of investment goods fall relative to nonliberalizers, even if this effect may be muted due to the presence of nontraded goods. The results conform to theory: liberalizers saw their investment goods price index fall by $0.166 \log$ points relative to nonliberalizers, and the difference is statistically significant at the $5 \%$ level. In absolute terms, investment goods prices actually rose slightly in nonliberalizers, but fell considerably among the liberalizers.

Panel (b) looks at the investment to GDP ratio from the World Bank's World Development Indicators. In the Solow variant of the model this ratio would rise due to relative price effects. In the Ramsey variant, a rise in the marginal product of capital (due to the fall in the "tax" on investment) would occasion an even larger increase in the investment share. The same would also be true in an open economy model with internationally mobile capital and costs of investment: with saving and investment decisions separable, and with the marginal product of capital rising, investment would also rise. The results conform to theory: liberalizers saw their investment share rise by $2.035 \%$ of GDP relative to nonliberalizers. Both groups saw their investment shares fall from the early to the late period, reflecting a global slowdown in investment and growth from one period to the next (cf. Dollar and Kraay 2004). But the difference-in-difference cares not about factors common to both treatment and control groups, only their differences. By this reckoning, the nonliberalizers suffered a large investment collapse $(-2.2 \%)$, while the liberalizers saw little change $(-0.2 \%)$.

Panel (c) looks at the total capital inflow to GDP ratio (measured by the financial account). This variable did not appear in our baseline models with immobile capital, but it would be present in similar open economy models with internationally mobile capital. Positive news for investment and growth would, all else equal, increase investment. It could also decrease saving (due to intertemporal smoothing against higher future income). The results conform to theory again: liberalizers saw their capital inflows accelerate relative to nonliberaliers, by $+0.620 \%$ of 
GDP. But what is striking in the underlying data is that although nonliberalizers saw inflows $(+1.597 \%)$ turn around into outflows $(-0.932 \%)$, the liberalizers managed to remain net recipients of capital $(-3.699 \%$ rising to only $-1.790 \%)$. In an era when capital seemed to flow mysteriously "uphill" from poor to rich countries - and the United States in particular emerged as a major borrower - the liberalizing countries in our sample stand out as a rare example of continued "downhill" capital flow, as theory would predict. However, we note the difference in total capital flows is not statistically significant $(p=0.489)$.

To provide some clarification of this finding, panel (d) isolates the changes in private capital flows. As is well known, many emerging markets and developing countries have been amassing large official reserves in the last decade or two, so the reserve part of the financial account (the official settlements balance) may give a distorted picture of the incentives for private capital flows. For example, governments and central banks might be piling up reserves for mercantilist reasons or as a buffer to guard against sudden stops or sudden flights (Aizenman and Noy 2008; Jeanne 2007; Obstfeld, Shambaugh, and Taylor 2008). In that case, this extra precautionary saving should be factored out before attempting to deduce shifts in market-directed capital flows. As panel (d) reveals, the ability of liberalizers to continue to attract private capital flows relative to nonliberalizers was even more dramatic than for total flows, a difference of $+1.948 \%$ of GDP, which is statistically significant at a not-so marginal $7 \%$ level. Private capital inflows to nonliberalizers collapsed from $2.419 \%$ to $0.320 \%$, but liberalizers saw almost no change in their private capital inflows, which fell only slightly from $1.925 \%$ to $1.773 \%$ of GDP. These results suggest that financial liberalization could be seen as a key complementary reform, allowing trade liberalizers to better finance their post-reform investment needs, a topic for future research. ${ }^{17}$

These results on key correlates suggest that the theoretical mechanisms proposed to explain higher growth were also operating in the right directions to lower capital prices, boost investment, and encourage private capital flows to those countries that liberalized.

\section{Conclusions}

Despite the predictions of theory, it is now unfashionable to argue that lower trade barriers will make developing countries better off, via faster growth in the medium run and higher output in the longer run. The argument seems to have failed because little robust evidence has been assembled - a result of poor empirical design, data scarcity, and a focus on sample periods when relatively little experimentation with trade policy actually occurred. We sought to overcome these obstacles by using a more suitable experimental design, collecting and assembling new data, and focusing on periods that bracket the watershed event in trade policy for developing countries, the Uruguay Round of GATT.

What can we conclude? We think these results show that there is quite strong support for the trade policy prescriptions of the 1990s Washington Consensus. The WC claimed that lowering

${ }^{17}$ See Henry (2007) for an example of a study of the gains from financial liberalization using the "policy experiment" approach favored in this paper. 
tariffs would promote growth in the developing world. Theory suggests a mechanism: lower tariffs will lead to cheaper capital and intermediate goods imports. The only way to test the claim is after the fact, by looking at which countries took this "medicine" and how they fared relative to those that didn't, using a classic treatment-and-control method to detect acceleration effects.

The results run contrary to the view that trade liberalization has failed to deliver growth benefits. They also contrast with influential cross-country empirical work that documents a weak or nonexistent relationship between tariffs levels and growth rates in the pre-1990 (pre-WC) period. That may have been the case then, but these earlier studies were almost surely hobbled by omitted variables and most certainly could not examine post-Uruguay, post-WC policy changes and economic performance. As Figure 4 shows, the Great Liberalization of the 1990s constitutes the great trade policy experiment of our era, and only now can we begin to evaluate its impact.

We have to be concerned not to oversell these results. WC supporters have been faulted for expecting implausibly high impacts from their policy prescriptions. Based on our empirics, all we can say is that the impact of tariff reduction looks quite beneficial and has a plausible magnitude consistent with theory. The effects we find are not so large as to be dismissed as implausible like some of the claims encountered in the WC debate, but at the same time our effects are still large enough to make a nontrivial cumulative difference in outcomes over the long run. Our results show that liberalizers have grown faster than nonliberalizers after this "experiment" - a result that survives in multiple specifications. Our findings are summarized in Figure 6, which shows growth accelerations for liberalizers and nonliberalizers (based on our preferred tariff measure for capital and intermediate goods). The level of GDP per worker is shown relative to the baseline trend for each group during the 1975-89 "before" period. Liberalizers clearly accelerated, whilst nonliberalizers stagnated. After 15 years, the difference between the two is about $15 \%-20 \%$, implying a differential acceleration of about $1 \%$ per annum in favor of the liberalizers, in line with the basic results of Table $1 .{ }^{18}$

An extra $1 \%$ of growth each year may not sound like a lot. It is surely small compared to what "institutional convergence" might deliver, by which poor-country TFP levels could be raised to OECD levels - but there are few credible prescriptions to achieve that goal. Moreover, is there any other single policy prescription of the last 20 years that can be argued to have contributed between $15 \%-20 \%$ to developing country incomes? To see the impact in a different perspective, we can also consider the growth needed to reduce poverty in accordance with the Millennium Development Goals. As noted by Kraay (2007, 140-41), an extra 1\% of growth is sufficient on its own to meet that goal in several developing countries, and it would make a contribution of between one half and one third to achieving that goal in many other countries. So the impact is hardly negligible and, for the mass of people clustered near the poverty line, a 15\%-20\% GDP boost over 15 years will make a very tangible difference.

\footnotetext{
${ }^{18}$ Although our methods for identifying liberalizations are different, as noted earlier, this $1 \%$ per annum impact is broadly consistent with other recent findings based on treatment-control or difference-in-difference methods (Dollar and Kraay 2004; Wacziarg and Welch 2008).
} 
In summary, the results serve to remind us of a nuanced but often overlooked point about trade policy in developing countries. It is the structure of protection, as much as its level, that matters for growth. Poor countries are net importers of capital goods, and most are net importers of intermediate goods too. Demand for some types of goods, such as advanced equipment and machines, is satisfied almost wholly by imports. Long ago, Díaz Alejandro (1970) pointed out that if-like the Argentines-you double the price of a machine via trade barriers, then you are placing an enormous tax on investment and accumulation that will depress output. Historical evidence accords with his view (De Long and Summers 1991; Jones 1994; Taylor 1994, 1998) Consumption tariffs may have limited or ambiguous impacts on growth (welfare is another matter), but capital and intermediate tariffs impose a very clear cost on national efficiency.

Recent trade liberalizations - and their intellectual underpinnings, whether we label them the "Washington Consensus" or not-should take some credit for unwinding many of those inefficiencies from the 1980s to today. Where those barriers have dropped growth accelerations have been significantly higher than where barriers have remained. Some countries have reaped the benefits. More could yet do so and enjoy higher incomes and lower poverty rates - but this is less likely to happen if any new consensus says that trade policy doesn't matter very much.

\section{References}

Acemoglu, Daron, Simon Johnson, and James A. Robinson. 2001. The Colonial Origins of Comparative Development: An Empirical Investigation. American Economic Review 91(5): 1369-1401.

Aizenman, Joshua, and Jaewoo Lee. 2008. Financial versus Monetary Mercantilism: Long-run View of Large International Reserves Hoarding. World Economy 31(5): 593-611.

Alcalá, Francisco, and Antonio Ciccone. 2004. Trade and Productivity. Quarterly Journal of Economics 119(2): 612-45.

Anderson, Kym, and Will Martin. 2005. Agricultural Trade Reform and the Doha Development Agenda. World Economy 28(9): 1301-27.

Baldwin, Richard E. 1992. Measurable Dynamic Gains from Trade. Journal of Political Economy 100: $162-74$.

Barro, Robert J. 1991. Economic Growth in a Cross Section of Countries. Quarterly Journal of Economics 106(2): 407-43.

Barro, Robert J., and Jong-Wha Lee. 2000. International Data on Educational Attainment: Updates and Implications. Unpublished, Harvard University, February.

Bertrand, Marianne. Esther Duflo, and Sendhil Mullainathan, 2004. How Much Should We Trust Differences-in-Differences Estimates? Quarterly Journal of Economics 119(1): 249-75.

Bhagwati, Jagdish. 2008. Termites in the Trading System: How Preferential Agreements Undermine Free Trade. Oxford: Oxford University Press.

Caselli, Francesco, Gerardo Esquivel, and Fernando Lefort. 1996. Reopening the Convergence Debate: A New Look at Cross-Country Growth Empirics. Journal of Economic Growth 1(3): 363-89.

De Long, J. Bradford, and Lawrence H. Summers. 1991. Equipment Investment and Economic Growth. Quarterly Journal of Economics 106(2): 445-502.

Díaz-Alejandro, Carlos F. 1970. Essays on the Economic History of the Argentine Republic. New Haven, Conn.: Yale University Press.

Dollar, David. 1992. Outward-Oriented Developing Economies Really Do Grow More Rapidly: Evidence from 95 LDCs, 1976-1985. Economic Development and Cultural Change 40(3): 523-44.

Dollar, David, and Aart Kraay. 2004. Trade, Growth, and Poverty. Economic Journal 114(493): F22-F49. 
Dowrick, Steve, and Mark Rogers. 2002. Classical and Technological Convergence: Beyond the SolowSwan Growth Model. Oxford Economic Papers 54(3): 369-85.

Easterly, William. 2005. National Policies and Economic Growth: A Reappraisal. In Handbook of Economic Growth, volume 1, edited by Philippe Aghion and Steven Durlauf. Amsterdam: Elsevier, 1015-59.

Easterly, William, Michael Kremer, Lant Pritchett, and Lawrence H. Summers. 1993. Good policy or good luck? Country growth performance and temporary shocks. Journal of Monetary Economics 32(3): 459-83.

Easterly, William, and Levine, Ross. 2003. Tropics, germs, and crops: how endowments influence economic development. Journal of Monetary Economics 50(1): 3-39.

Edwards, Sebastian, 1998. Openness, Productivity and Growth: What Do We Really Know? Economic Journal 108(447): 383-98.

Estevadeordal, Antoni, Brian Frantz, and Alan M. Taylor. 2003. The Rise And Fall Of World Trade, 1870-1939. Quarterly Journal of Economics 118(2): 359-407.

Estevadeordal, Antoni, Caroline Freund, and Emanuel Ornelas. 2008. Does Regionalism Affect Trade Liberalization Towards Non-Members? Quarterly Journal of Economics 123(4). Forthcoming.

Gallup, John Luke, Jeffrey D. Sachs, and Andrew D. Mellinger. 1999. Geography and Economic Development. International Regional Science Review 22(2): 179-232.

Glaeser, Edward L., Rafael La Porta, Florencio Lopez-de-Silanes, and Andrei Shleifer. 2004. Do Institutions Cause Growth? Journal of Economic Growth 9(3): 271-303.

Glick, Reuven, and Alan M. Taylor. Forthcoming. Collateral Damage: Trade Disruption and the Economic Impact of War. Review of Economics and Statistics.

Gollin, Douglas. 2002. Getting Income Shares Right. Journal of Political Economy 110(2): 458-74.

Harrison, Ann, 1996. Openness and Growth: A Time-Series, Cross-Country Analysis for Developing Countries. Journal of Development Economics 48(2): 419-47.

Hausmann, Ricardo, Lant Pritchett, and Dani Rodrik. 2005. Growth Accelerations. Journal of Economic Growth 10(4): 303-29.

Henry, Peter Blair. 2007. Capital Account Liberalization: Theory, Evidence, and Speculation. Journal of Economic Literature 45(4): 887-935.

Hsieh, Chang-Tai, and Peter J. Klenow. 2007. Relative Prices and Relative Prosperity. American Economic Review 97(3): 562-85.

Jeanne, Olivier. 2007. International Reserves in Emerging Market Countries: Too Much of a Good Thing? Brookings Papers on Economic Activity 1: 1-79.

Jones, Charles I. 1994. Economic growth and the relative price of capital. Journal of Monetary Economics 34(3): 359-82.

Jones, Charles I. 2008. Intermediate Goods, Weak Links, and Superstars: A Theory of Economic Development. NBER Working Papers 13834.

Kindleberger, Charles P. 1989. Commercial Policy Between the Wars. In The Cambridge Economic History of Europe, vol. 8, edited by P. Mathias and S. Pollard. Cambridge: Cambridge University Press.

Kono, Daniel. 2006. Optimal Obfuscation: Democracy and Trade Policy Transparency. American Political Science Review 100(3): 369-384.

Kraay, Aart. 2007. "Comment [on William Easterly]" In Globalization and Poverty: An Introduction edited by Ann Harrison. Chicago: University of Chicago Press, 134-42.

Kremer, Michael. 1993. The O-Ring Theory of Economic Development. Quarterly Journal of Economics 108(3): 551-75.

Lee, Jong-Wha, 1995. Capital goods imports and long-run growth. Journal of Development Economics 48(1): 91-110.

Maddison, Angus. 2001. The World Economy: Historical Statistics. Paris: OECD.

Mankiw, N. Gregory, David Romer, and David N. Weil. 1992. A Contribution to the Empirics of Economic Growth. Quarterly Journal of Economics 107(2): 407-37. 
Mazumdar, Joy. 1996. Do Static Gains from Trade Lead to Medium-Run Growth? Journal of Political Economy 104 (6): 1328-37.

Noguer, Marta, and Siscart, Marc. 2005. Trade raises income: a precise and robust result. Journal of International Economics 65(2): 447-60.

Obstfeld, Maurice, Shambaugh, Jay C., and Taylor, Alan M. 2008. Financial Stability, the Trilemma, and International Reserves. CEPR Discussion Papers no. 6693.

Polanyi, Karl. 1944. The Great Transformation: The Political and Economic Origins of Our Time. New York: Farrar and Rinehart,

Rodríguez, Francisco. 2007. Openness and Growth: What Have We Learned? In Growth Divergences: Explaining Differences in Economic Performance edited by José Antonio Ocampo, Jomo K. S., and Rob Vos. New York: Zed Books.

Rodríguez, Francisco, and Dani Rodrik. 2001. Trade Policy and Economic Growth: A Skeptic's Guide to the Cross-National Literature. In NBER Macroeconomics Annual 2000 edited by Ben S. Bernanke and Kenneth Rogoff. Cambridge, Mass.: MIT Press.

Rodrik, Dani. 2006. Goodbye Washington Consensus, Hello Washington Confusion? A Review of the World Bank's "Economic Growth in the 1990s: Learning from a Decade of Reform." Journal of Economic Literature 44 (December): 973-87.

Rodrik, Dani, Arvind Subramanian, and Francesco Trebbi. 2004. Institutions Rule: The Primacy of Institutions over Geography and Integration in Economic Development. Journal of Economic Growth 9(2): 131-65.

Rose, Andrew K. 2004. Do We Really Know That the WTO Increases Trade? American Economic Review 94(1): 98-114.

Rose, Andrew K. 2007. The Foreign Service and Foreign Trade: Embassies as Export Promotion. The World Economy 30 (1): 22-38

Ruggie, John Gerard. 1982. International Regimes, Transactions, and Change: Embedded Liberalism in the Postwar Economic Order. International Organization 36(2): 379-415.

Sachs, Jeffrey D., and Warner, Andrew M. 1995. Economic reform and the process of global integration. Brookings Papers on Economic Activity 1-118.

Siegler, Mark V., and Van Gaasbeck, Kristin A. 2005. From the Great Depression to the Great Inflation: Path dependence and monetary policy. Journal of Economics and Business 57(5): 375-87.

Slaughter, Matthew J. 2001. Trade Liberalization and Per Capita Income Convergence: A Difference-InDifferences Analysis. Journal of International Economics 55(1): 203-28.

Taylor, Alan M. 1994. Tres fases del crecimiento económico argentino. Revista de Historia Económica 12 (Otoño): 649-83.

Taylor, Alan M. 1998. Argentina and the World Capital Market: Saving, Investment, and International Capital Mobility in the Twentieth Century. Journal of Development Economics 57 (October): $147-84$.

Wacziarg, Romain, and Karen Horn Welch. 2008. Trade Liberalization and Growth: New Evidence. World Bank Economic Review 22(2): 187-231.

Warner, Andrew M. 2003. Once More into the Breach: Economic Growth and Integration. Working Paper no. 34, Center for Global Development.

Williamson, John, ed. 1990. Latin American Adjustment: How Much Has It Happened? Washington, D.C.: Institute for International Economics.

World Bank. 2005. Economic Growth in the 1990s: Learning from a Decade of Reform. Washington, D.C.: World Bank. 
Table 1

\section{Discrete Treatment Variable: Difference in Difference Regressions}

(a) Without controls

\begin{tabular}{|l|c|c|c|c|c|}
\hline Sample & Full & Restricted & Restricted & Restricted & Restricted \\
\hline Tariff measure & Average & Consumption & Capital & Intermediate & $\begin{array}{c}\text { Capital \& } \\
\text { Intermediate }\end{array}$ \\
\hline & $(1)$ & $(2)$ & $(3)$ & $(4)$ & $(5)$ \\
\hline Liberalizer indicator & $0.0114^{*}$ & $0.00875^{*}$ & $0.00960 * *$ & $0.00847 *$ & $0.0109 * *$ \\
\hline & $(0.0046)$ & $(0.0045)$ & $(0.0044)$ & $(0.0045)$ & $(0.0044)$ \\
\hline Observations & 75 & 47 & 47 & 47 & 47 \\
\hline R-squared & 0.08 & 0.08 & 0.09 & 0.07 & 0.12 \\
\hline
\end{tabular}

(b) With growth model controls

\begin{tabular}{|l|c|c|c|c|c|}
\hline & $(1)$ & $(2)$ & $(3)$ & $(4)$ & $(5)$ \\
\hline Liberalizer indicator & $0.00717 *$ & $0.00842^{* *}$ & $0.00862^{* *}$ & $0.00898^{* *}$ & $0.00952^{* *}$ \\
\hline Growth lagged & $(0.0037)$ & $(0.0038)$ & $(0.0037)$ & $(0.0036)$ & $(0.0036)$ \\
\hline & $-0.574 * * *$ & $-0.532^{* * *}$ & $-0.518 * * *$ & $-0.547 * * *$ & $-0.522^{* * *}$ \\
\hline Change in schooling & $(0.079)$ & $(0.094)$ & $(0.094)$ & $(0.092)$ & $(0.092)$ \\
\hline & -0.000346 & 0.00149 & 0.00129 & 0.00110 & 0.00149 \\
\hline Change in institutions & $(0.0027)$ & $(0.0030)$ & $(0.0030)$ & $(0.0030)$ & $(0.0029)$ \\
\hline & $0.0271 *$ & 0.0212 & 0.0178 & 0.0171 & 0.0188 \\
\hline Observations & $(0.014)$ & $(0.018)$ & $(0.017)$ & $(0.017)$ & $(0.017)$ \\
\hline R-squared & 70 & 44 & 4 & 44 & 4 \\
\hline
\end{tabular}

(c) Excluding institutions and schooling

\begin{tabular}{|l|c|c|c|c|c|}
\hline & $(1)$ & $(2)$ & $(3)$ & $(4)$ & $(5)$ \\
\hline Liberalizer indicator & 0.00373 & $0.00792^{* *}$ & $0.00774 * *$ & $0.00907 * *$ & $0.00947 * *$ \\
\hline Growth lagged & $(0.0035)$ & $(0.0035)$ & $(0.0035)$ & $(0.0034)$ & $(0.0034)$ \\
\hline & $-0.586 * * *$ & $-0.496 * * *$ & $-0.486 * * *$ & $-0.512 * * *$ & $-0.487 * * *$ \\
\hline Observations & $(0.073)$ & $(0.088)$ & $(0.088)$ & $(0.086)$ & $(0.086)$ \\
\hline R-squared & 75 & 47 & 47 & 47 & 47 \\
\hline
\end{tabular}

(d) Excluding institutions and schooling and with the sample restricted to developing countries only

\begin{tabular}{|l|c|c|c|c|c|}
\hline & $(1)$ & $(2)$ & $(3)$ & $(4)$ & $(5)$ \\
\hline Liberalizer indicator & 0.00561 & 0.00818 & 0.00795 & $0.0114 * *$ & $0.0108 * *$ \\
\hline Growth lagged & $(0.0048)$ & $(0.0053)$ & $(0.0053)$ & $(0.0052)$ & $(0.0052)$ \\
\hline & $-0.595 * * *$ & $-0.472 * * *$ & $-0.461 * * *$ & $-0.483 * * *$ & $-0.462 * * *$ \\
\hline Observations & $(0.080)$ & $(0.11)$ & $(0.11)$ & $(0.10)$ & $(0.10)$ \\
\hline R-squared & 53 & 31 & 31 & 31 & 31 \\
\hline
\end{tabular}

Dependent variable is difference in the average change per annum of log GDP per worker.

Period 1 is $1975-1989$ and period 2 is $1990-2004$.

Developing countries are those with IMF IFS codes 186 (Turkey), 199 (South Africa), plus all codes 200 and higher.

Full sample uses EFW trade taxes as a tariff proxy. Restricted sample uses disaggregated tariff data.

Tariffs are measured in 1985 and 2000 or closest date thereto.

Standard errors in parentheses. Constant terms not reported.

$*$ significant at $10 \%$; ** significant at $5 \%$; *** significant at $1 \%$. 
Table 2

Continuous Treatment Variable: Difference Regressions

(a) No controls

\begin{tabular}{|l|c|c|c|c|c|}
\hline Sample & Full & Restricted & Restricted & Restricted & Restricted \\
\hline Tariff measure & Average & Consumption & Capital & Intermediate & $\begin{array}{c}\text { Capital \& } \\
\text { Intermediate }\end{array}$ \\
\hline & $(1)$ & $(2)$ & $(3)$ & $(4)$ & $(5)$ \\
\hline$\Delta \ln (1+$ tariff $)$ & $-0.0519^{* * *}$ & $-0.0222^{*}$ & $-0.0516^{* *}$ & $-0.0316^{*}$ & $-0.0407^{* *}$ \\
\hline & $(0.019)$ & $(0.013)$ & $(0.023)$ & $(0.017)$ & $(0.020)$ \\
\hline Observations & 75 & 47 & 47 & 47 & 47 \\
\hline R-squared & 0.09 & 0.06 & 0.10 & 0.07 & 0.08 \\
\hline
\end{tabular}

(b) With growth model controls

\begin{tabular}{|l|c|c|c|c|c|}
\hline & $(1)$ & $(2)$ & $(3)$ & $(4)$ & $(5)$ \\
\hline$\Delta \ln (1+$ tariff $)$ & $-0.0270^{*}$ & $-0.0199^{*}$ & $-0.0378^{*}$ & $-0.0285^{*}$ & $-0.0333^{*}$ \\
\hline & $(0.015)$ & $(0.011)$ & $(0.019)$ & $(0.014)$ & $(0.016)$ \\
\hline Growth lagged & $-0.576^{* * *}$ & $-0.541^{* * *}$ & $-0.524^{* * *}$ & $-0.541^{* * *}$ & $-0.534^{* * *}$ \\
\hline & $(0.079)$ & $(0.096)$ & $(0.096)$ & $(0.095)$ & $(0.095)$ \\
\hline Change in schooling & -0.000299 & 0.00179 & 0.000942 & 0.000591 & 0.000722 \\
\hline & $(0.0027)$ & $(0.0031)$ & $(0.0030)$ & $(0.0030)$ & $(0.0030)$ \\
\hline Change in institutions & $0.0234 *$ & 0.0180 & 0.0123 & 0.0120 & 0.0123 \\
\hline & $(0.014)$ & $(0.018)$ & $(0.017)$ & $(0.017)$ & $(0.017)$ \\
\hline Observations & 70 & 44 & 44 & 44 & 44 \\
\hline R-squared & 0.57 & 0.50 & 0.51 & 0.51 & 0.51 \\
\hline
\end{tabular}

(c) Excluding institutions and schooling

\begin{tabular}{|l|c|c|c|c|c|}
\hline & $(1)$ & $(2)$ & $(3)$ & $(4)$ & $(5)$ \\
\hline$\Delta \ln (1+$ tariff $)$ & -0.0226 & $-0.0210^{* *}$ & $-0.0430^{* *}$ & $-0.0325^{* *}$ & $-0.0382^{* *}$ \\
\hline & $(0.014)$ & $(0.0100)$ & $(0.018)$ & $(0.013)$ & $(0.015)$ \\
\hline Growth lagged & $-0.579 * * *$ & $-0.501^{* * *}$ & $-0.487 * * *$ & $-0.507 * * *$ & $-0.499^{* * *}$ \\
\hline & $(0.072)$ & $(0.088)$ & $(0.088)$ & $(0.087)$ & $(0.087)$ \\
\hline Observations & 75 & 47 & 47 & 47 & 47 \\
\hline R-squared & 0.52 & 0.46 & 0.47 & 0.47 & 0.48 \\
\hline
\end{tabular}

(d) Excluding institutions and schooling and with the sample restricted to developing countries only

\begin{tabular}{|l|c|c|c|c|c|}
\hline & $(1)$ & $(2)$ & $(3)$ & $(4)$ & $(5)$ \\
\hline Liberalizer indicator & -0.0237 & -0.0198 & $-0.0453^{*}$ & $-0.0321^{*}$ & $-0.0389^{*}$ \\
\hline & $(0.016)$ & $(0.013)$ & $(0.024)$ & $(0.017)$ & $(0.021)$ \\
\hline Growth lagged & $-0.591^{* * *}$ & $-0.470^{* * *}$ & $-0.454^{* * *}$ & $-0.476^{* * *}$ & $-0.467 * * *$ \\
\hline & $(0.079)$ & $(0.11)$ & $(0.11)$ & $(0.11)$ & $(0.10)$ \\
\hline Observations & 53 & 31 & 31 & 31 & 31 \\
\hline R-squared & 0.57 & 0.44 & 0.46 & 0.46 & 0.46 \\
\hline
\end{tabular}

Dependent variable is difference in the average change per annum of log GDP per worker.

Period 1 is $1975-1989$ and period 2 is $1990-2004$.

Developing countries are those with IMF IFS codes 186 (Turkey), 199 (South Africa), plus all codes 200 and higher.

Full sample uses EFW trade taxes as a tariff proxy. Restricted sample uses disaggregated tariff data.

Tariffs are measured in 1985 and 2000 or closest date thereto.

Standard errors in parentheses. Constant terms not reported.

$*$ significant at $10 \% ; * *$ significant at $5 \%$; ** significant at $1 \%$. 
Table 3

Institutions and Trade Policy: Correlation in Levels but Not in Changes

(a) All countries

\begin{tabular}{|c|c|c|c|c|c|c|}
\hline & (1) & (2) & (3) & (4) & (5) & (6) \\
\hline & $\begin{array}{c}\ln (1+\mathrm{t}), \\
\text { lagged }\end{array}$ & $\begin{array}{l}\ln (1+\mathrm{t}), \\
\text { change }\end{array}$ & $\begin{array}{l}\ln (1+\mathrm{t}), \\
\text { change }\end{array}$ & $\begin{array}{l}\ln (1+\mathrm{t}), \\
\text { lagged }\end{array}$ & $\begin{array}{l}\ln (1+\mathrm{t}), \\
\text { change }\end{array}$ & $\begin{array}{l}\ln (1+\mathrm{t}), \\
\text { change }\end{array}$ \\
\hline \multirow[t]{2}{*}{ Institutions, lagged } & -0.415 & 0.211 & & & & \\
\hline & $(0.071) * * *$ & $(0.068) * * *$ & & & & \\
\hline \multirow{2}{*}{ Institutions, change } & & & 0.159 & & & \\
\hline & & & $(0.106)$ & & & \\
\hline \multirow[t]{2}{*}{ Political liberty, lagged } & & & & -0.148 & 0.053 & \\
\hline & & & & $(0.040) * * *$ & $(0.370)^{* *}$ & \\
\hline \multirow[t]{2}{*}{ Political liberty, change } & & & & & & -0.054 \\
\hline & & & & & & $(0.056)$ \\
\hline Observations & 91 & 83 & 83 & 84 & 79 & 74 \\
\hline R-squared & 0.28 & 0.11 & 0.03 & 0.14 & 0.03 & 0.01 \\
\hline
\end{tabular}

(b) Developing countries only

\begin{tabular}{|l|c|c|c|c|c|c|}
\hline & $(1)$ & $(2)$ & $(3)$ & $(4)$ & $(5)$ & $(6)$ \\
\hline & $\begin{array}{c}\ln (1+\mathrm{t}), \\
\text { lagged }\end{array}$ & $\begin{array}{c}\ln (1+\mathrm{t}), \\
\text { change }\end{array}$ & $\begin{array}{c}\ln (1+\mathrm{t}), \\
\text { change }\end{array}$ & $\begin{array}{c}\ln (1+\mathrm{t}), \\
\text { lagged }\end{array}$ & $\begin{array}{c}\ln (1+\mathrm{t}), \\
\text { change }\end{array}$ & $\begin{array}{c}\ln (1+\mathrm{t}), \\
\text { change }\end{array}$ \\
\hline Institutions, lagged & -0.277 & 0.231 & & & & \\
\hline Institutions, change & $(0.123)^{* *}$ & $(0.127)^{*}$ & & & & \\
\hline & & & 0.136 & & & \\
\hline Political liberty, lagged & & & $(0.126)$ & & -0.023 & \\
\hline & & & & 0.019 & $(0.058)$ & \\
\hline Political liberty, change & & & & & & -0.036 \\
\hline & & & & & & \\
\hline Observations & 69 & 61 & 61 & 62 & 57 & $(0.069)$ \\
\hline R-squared & 0.07 & 0.05 & 0.02 & 0.00 & 0.00 & 0.01 \\
\hline
\end{tabular}

Dependent variable is change or lag of $\log (1+$ average tariff $)$

Period 1 is $1975-1989$ and period 2 is 1990-2004

Tariffs are measured in 1985 and 2000 or closest date thereto.

Institutions is from Economic Freedom in the World (Area 2ab rescaled to 0-1).

Political Liberty is from Freedom House (rescaled to 0-1).

Developing countries are those with IMF IFS codes 186 (Turkey), 199 (South Africa), plus all codes 200 and higher.

Standard errors in parentheses. Constant terms not reported.

$*$ significant at $10 \%$; ** significant at $5 \%$; *** significant at $1 \%$. 
Table 4

IV Regressions 1

\begin{tabular}{|c|c|c|c|c|}
\hline & (1) & (2) & (3) & (4) \\
\hline & First stage & $\begin{array}{c}\text { Second } \\
\text { stage }\end{array}$ & First stage & $\begin{array}{l}\text { Second } \\
\text { stage }\end{array}$ \\
\hline & $\Delta \ln \left(1+t_{\text {Capital \& Intermediate }}\right)$ & $\Delta$ growth & $\Delta \ln \left(1+t_{\text {Capital \& Intermediate }}\right)$ & Dgrowth \\
\hline \multirow{2}{*}{ GATT Potential 1} & $-0.517 * * *$ & & $-0.548 * * *$ & \\
\hline & $(0.072)$ & & $(0.067)$ & \\
\hline \multirow[t]{2}{*}{$\Delta \ln \left(1+t_{\text {Capital \& Intermediate }}\right)$} & & $-0.0537 * *$ & & $-0.0482 * *$ \\
\hline & & $(0.021)$ & & $(0.021)$ \\
\hline \multirow[t]{2}{*}{ Growth lagged } & -0.0453 & $-0.496 * * *$ & 0.159 & $-0.524 * * *$ \\
\hline & $(0.58)$ & $(0.088)$ & $(0.56)$ & $(0.096)$ \\
\hline \multirow[t]{2}{*}{ Change in schooling } & & & -0.00648 & 0.000546 \\
\hline & & & $(0.018)$ & $(0.0031)$ \\
\hline \multirow[t]{2}{*}{ Change in institutions } & & & $0.291 * * *$ & 0.0146 \\
\hline & & & $(0.10)$ & $(0.017)$ \\
\hline Observations & 44 & 47 & 44 & 44 \\
\hline R-squared & 0.56 & 0.46 & 0.64 & 0.50 \\
\hline
\end{tabular}

Period 1 is $1975-1989$ and period 2 is 1990-2004

Tariffs are measured in 1985 and 2000 or closest date thereto.

$\Delta \ln \left(1+t_{\text {Capital \& Intermediate }}\right)$ is instrumented by GATT Potential 1 in columns 2 and 4 .

Standard errors in parentheses. Constant terms not reported.

$*$ significant at $10 \%$; ** significant at $5 \%$; *** significant at $1 \%$.

Table 5

IV Regressions 2

\begin{tabular}{|c|c|c|c|c|}
\hline & $(1)$ & $(2)$ & (3) & $(4)$ \\
\hline & First stage & $\begin{array}{c}\text { Second } \\
\text { stage }\end{array}$ & First stage & $\begin{array}{l}\text { Second } \\
\text { stage }\end{array}$ \\
\hline & $\Delta \ln \left(1+t_{\text {Capital \& Intermediate }}\right)$ & Dgrowth & $\Delta \ln \left(1+t_{\text {Capital \& Intermediate }}\right)$ & Dgrowth \\
\hline \multirow[t]{2}{*}{ GATT Potential 2} & $-0.650 * * *$ & & $-0.659 * * *$ & \\
\hline & $(0.025)$ & & $(0.027)$ & \\
\hline \multirow[t]{2}{*}{$\Delta \ln \left(1+t_{\text {Capital \& Intermediate }}\right)$} & & $-0.0541 * *$ & & $-0.0507 * *$ \\
\hline & & $(0.020)$ & & $(0.022)$ \\
\hline \multirow[t]{2}{*}{ Growth lagged } & 0.146 & $-0.394 * * *$ & 0.0942 & $-0.409 * * *$ \\
\hline & $(0.20)$ & $(0.11)$ & $(0.21)$ & $(0.12)$ \\
\hline \multirow[t]{2}{*}{ Change in schooling } & & & 0.00119 & 0.000792 \\
\hline & & & $(0.0061)$ & $(0.0033)$ \\
\hline \multirow[t]{2}{*}{ Change in institutions } & & & -0.0447 & -0.00697 \\
\hline & & & $(0.035)$ & $(0.018)$ \\
\hline Observations & 31 & 31 & 31 & 31 \\
\hline R-squared & 0.96 & 0.43 & 0.96 & 0.44 \\
\hline
\end{tabular}

Period 1 is $1975-1989$ and period 2 is 1990-2004

Tariffs are measured in 1985 and 2000 or closest date thereto.

$\Delta \ln \left(1+t_{\text {Capital \& Intermediate }}\right)$ is instrumented by GATT Potential 2 in columns 2 and 4 .

Standard errors in parentheses. Constant terms not reported.

* significant at $10 \%$; ** significant at $5 \%$; *** significant at $1 \%$. 
Table 6

Other Correlates

\begin{tabular}{|c|c|c|c|}
\hline Variable & $\begin{array}{l}\text { Difference in Difference: } \\
\text { Liberalizers minus Nonliberalizers, } \\
\text { After minus Before }\end{array}$ & $\begin{array}{l}\text { Liberalizers: } \\
\text { Before } \\
\text { After } \dagger\end{array}$ & $\begin{array}{l}\text { Nonliberalizers: } \\
\text { Before } \\
\text { After } \dagger\end{array}$ \\
\hline \multirow[t]{2}{*}{$\begin{array}{l}\text { (a) Log absolute price of investment goods } \\
\text { (Penn World Table) }\end{array}$} & $-0.166 * *$ & $\begin{array}{l}-0.241 \\
-0.370 \dagger\end{array}$ & $\begin{array}{l}-0.160 \\
-0.123 \dagger\end{array}$ \\
\hline & $\mathrm{N}=82, \mathrm{p}=.045$ & & \\
\hline \multirow[t]{2}{*}{$\begin{array}{l}\text { (b) Investment share of GDP, \% } \\
\text { (World Development Indicators) }\end{array}$} & $+2.035 *$ & $\begin{array}{l}20.891 \\
20.691 \dagger\end{array}$ & $\begin{array}{l}24.022 \\
21.787 \dagger\end{array}$ \\
\hline & $\mathrm{N}=83, \mathrm{p}=.054$ & & \\
\hline \multirow[t]{2}{*}{$\begin{array}{l}\text { (c) Total capital inflows as \% of GDP } \\
\text { (financial account, IFS) }\end{array}$} & +0.619 & $\begin{array}{l}+3.969 \\
+1.790 \dagger\end{array}$ & $\begin{array}{l}+1.597 \\
-0.932 \dagger\end{array}$ \\
\hline & $\mathrm{N}=58 \mathrm{p}=.489$ & & \\
\hline \multirow[t]{2}{*}{$\begin{array}{l}\text { (d) Private capital inflows as \% of GDP } \\
\text { (nonreserve financial account, IFS) }\end{array}$} & $+1.947 *$ & $\begin{array}{l}+1.925 \\
+1.773 \dagger\end{array}$ & $\begin{array}{l}+2.420 \\
+0.320 \dagger\end{array}$ \\
\hline & $\mathrm{N}=58, \mathrm{p}=.070$ & & \\
\hline
\end{tabular}

Notes: Liberalizers and nonliberalizers defined by average tariff. Before is 1975-1989. After is 1990-2004.

$*$ significant at $10 \%$; ** significant at $5 \%$; *** significant at $1 \%$. 
Figure 1: Growth Simulations When All Goods Are Traded.

(a) Solow

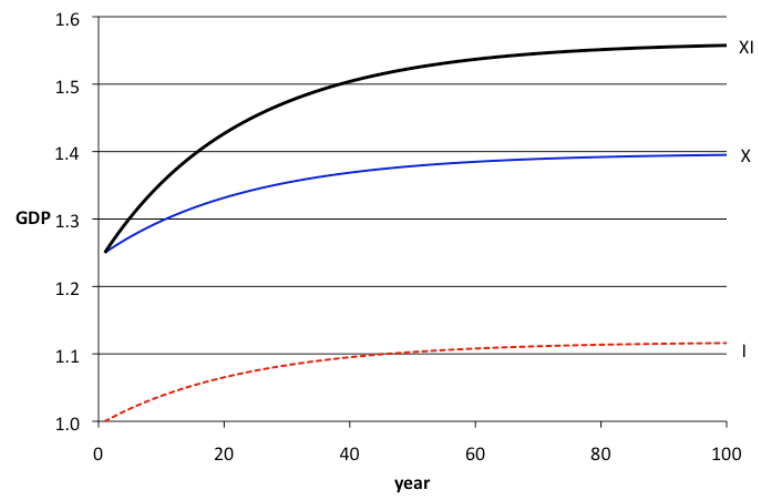

(b) Ramsey

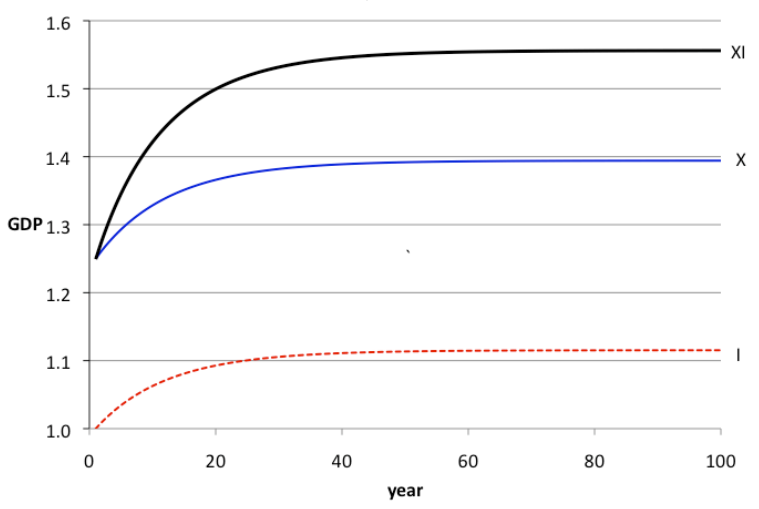

\begin{tabular}{|l|c|c|c|}
\hline $\begin{array}{l}\text { Increase in average growth rate } \\
\text { (\% per year) over first 15 years }\end{array}$ & $\begin{array}{c}\text { Remove 25\% } \\
\text { I tariff }\end{array}$ & $\begin{array}{c}\text { Remove 25\% } \\
\text { X tariff }\end{array}$ & $\begin{array}{c}\text { Remove 25\% } \\
\text { I and X tariffs }\end{array}$ \\
\hline Solow model & $0.36 \%$ & $1.85 \%$ & $2.25 \%$ \\
\hline Ramsey model & $0.54 \%$ & $2.02 \%$ & $2.60 \%$ \\
\hline
\end{tabular}

Notes: In the figure, the simulations are labeled as follows.

I: Remove 25\% I (capital goods) tariff

X: Remove 25\% X (intermediate goods) tariff

XI: Remove $25 \%$ I and X tariffs. 
Figure 2: Growth Simulations When Most X and I Goods Are Nontraded.

(a) Solow

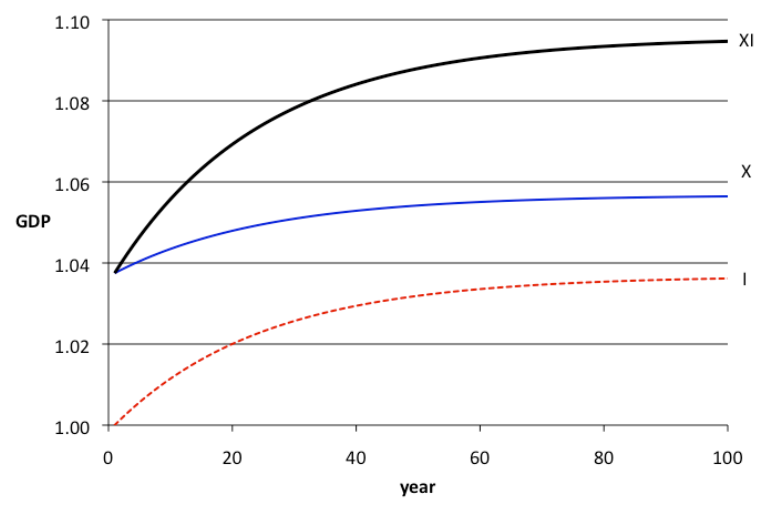

(b) Ramsey

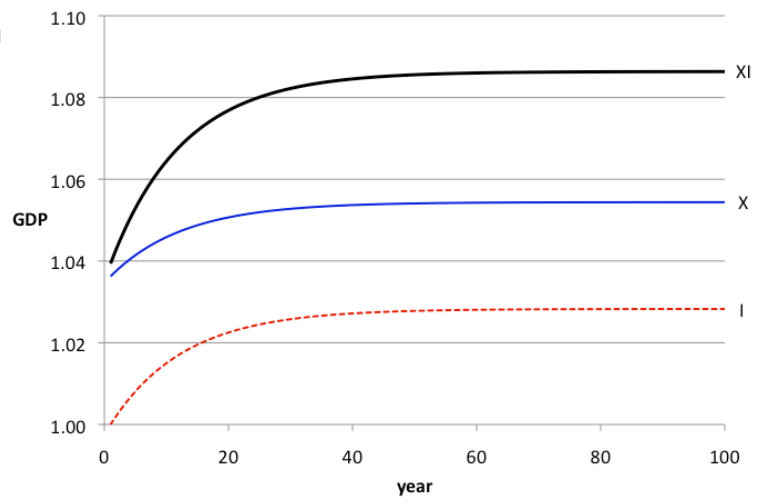

\begin{tabular}{|l|c|c|c|}
\hline $\begin{array}{l}\text { Increase in average growth rate } \\
\text { (\% per year) over first 15 years }\end{array}$ & $\begin{array}{c}\text { Remove 25\% } \\
\text { I tariff }\end{array}$ & $\begin{array}{c}\text { Remove 25\% } \\
\text { X tariff }\end{array}$ & $\begin{array}{c}\text { Remove 25\% } \\
\text { I and X tariffs }\end{array}$ \\
\hline Solow model & $0.11 \%$ & $0.30 \%$ & $0.42 \%$ \\
\hline Ramsey model & $0.13 \%$ & $0.32 \%$ & $0.47 \%$ \\
\hline
\end{tabular}

Notes: In the figure, the simulations are labeled as follows.

I: Remove $25 \%$ I (capital goods) tariff

X: Remove 25\% X (intermediate goods) tariff

XI: Remove $25 \%$ I and X tariffs. 
Figure 3: The Great Liberalization: Treatment and Control Groups

(a) Average tariffs, $\ln (1+t)$ : after versus before

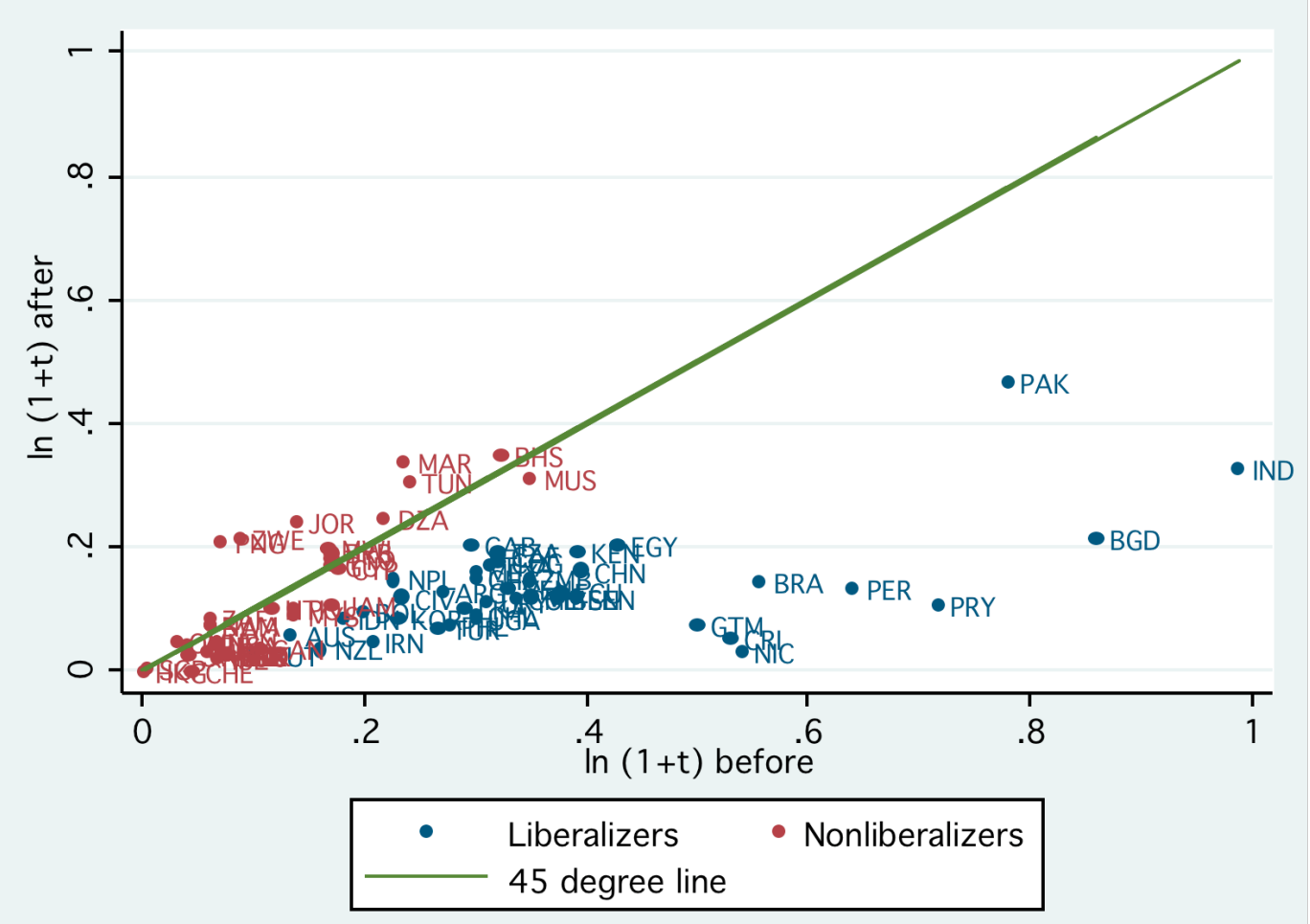

(b) Capital and intermediate goods tariffs, $\ln (1+\mathrm{tki})$ : after versus before

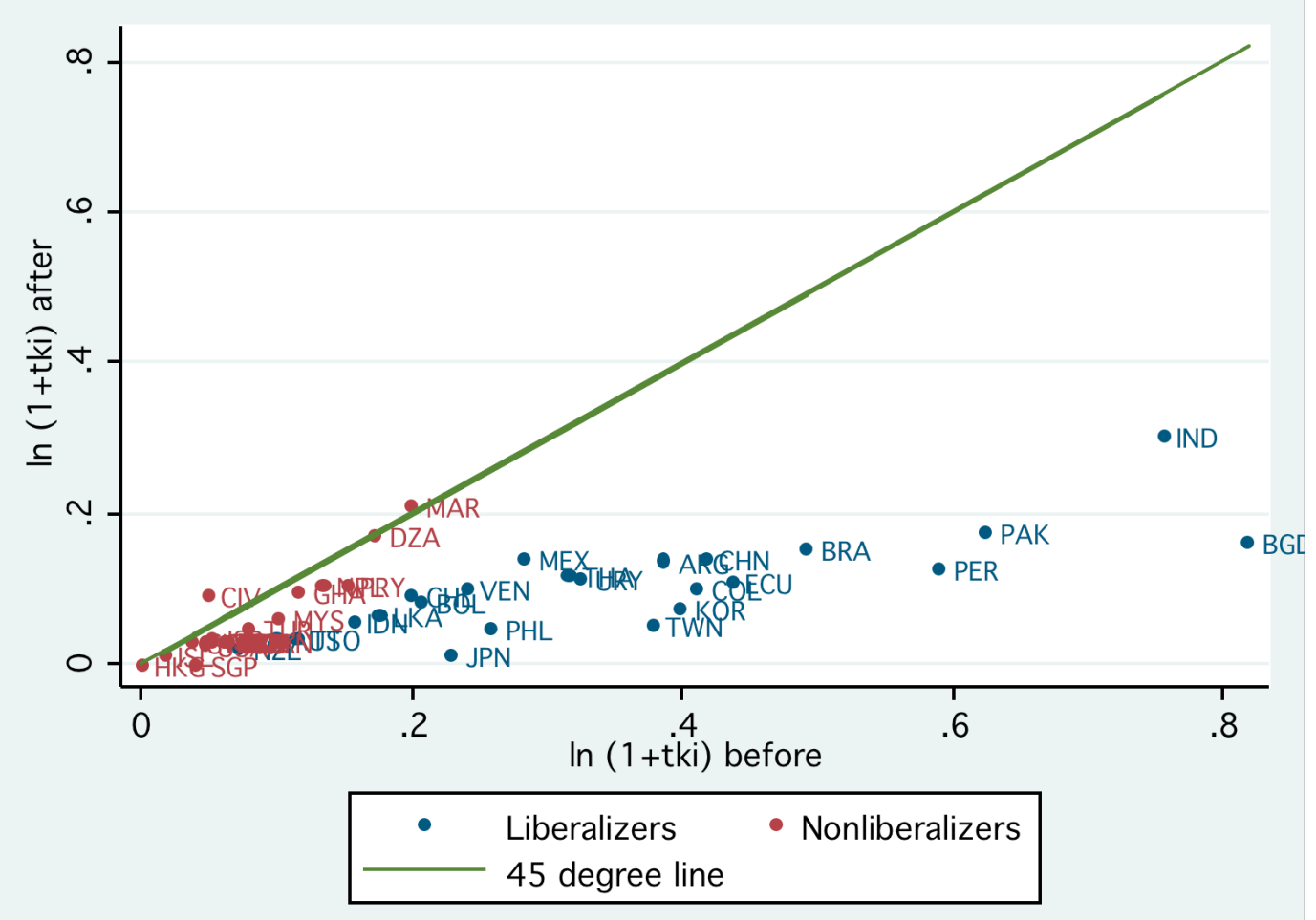




\section{Figure 4: The Great Liberalization: Trends in Tariffs}

(a) Average tariffs in Developed versus Developing

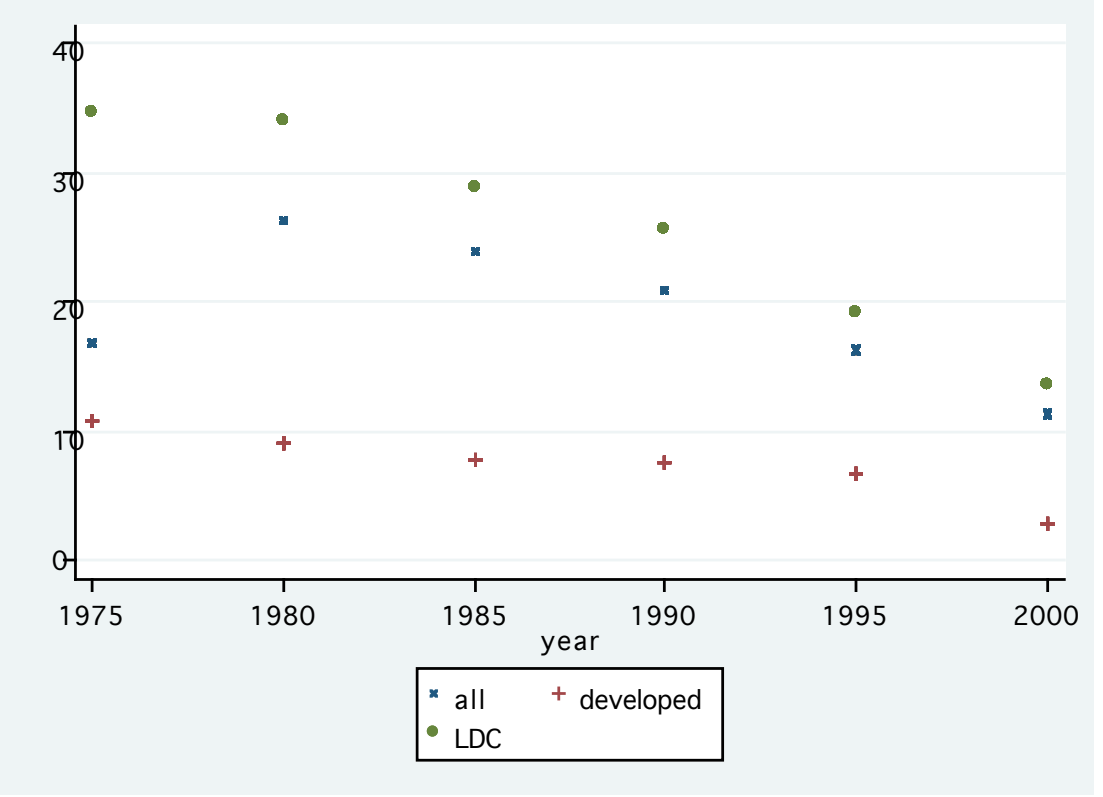

(b) Average tariffs in Liberalizers versus Nonliberalizers

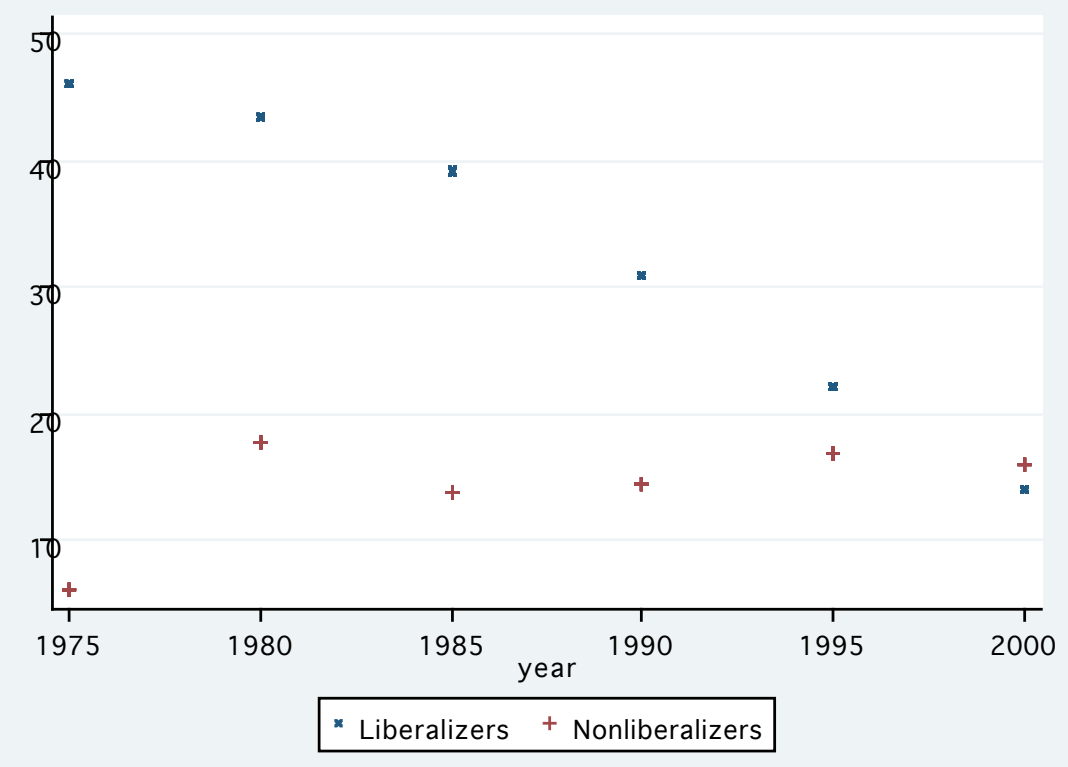

Notes: The samples are as follows $(*=$ developing country).

Liberalizers: Austria, Turkey*, Australia, New Zealand, Argentina*, Bolivia*, Brazil*, Chile*, Colombia*, Costa Rica*, Ecuador*, Guatemala*, Mexico*, Nicaragua*, Paraguay*, Peru*, Uruguay*, Venezuela*, Iran*, Egypt*, Bangladesh*, Sri Lanka*, India*, Indonesia*, South Korea*, Nepal*, Pakistan*, Philippines*, Thailand*, Central Afr. Rep.*, Congo, Rep. Of*, Benin*, Gabon*, Ghana*, Cote d'Ivoire*, Kenya*, Mali*, Senegal*, Tanzania*, Uganda*, Zambia*, China*.

Nonliberalizers: United States, United Kingdom, Belgium, Denmark, France, Germany, Italy, Luxembourg, Netherlands, Norway, Sweden, Switzerland, Canada, Japan, Finland, Greece, Iceland, Ireland, Spain, South Africa*, Oman*, Unit. Arab Em.*, Hong Kong*, Malaysia*, Singapore*, Botswana*, Namibia*, Haiti*, Bahamas*, Barbados*, Guyana*, Jamaica*, Trinidad \& Tob.*, Cyprus*, Jordan*, Algeria*, Malawi*, Mauritius*, Morocco*, Zimbabwe*, Tunisia*, Pap. New Guinea*, Poland*. 
Figure 5: Instruments Are Not Weak

(a) Bivariate Scatter of change in tariff versus GATT Potential 1 using GATT Membership in 1975 times log initial tariff

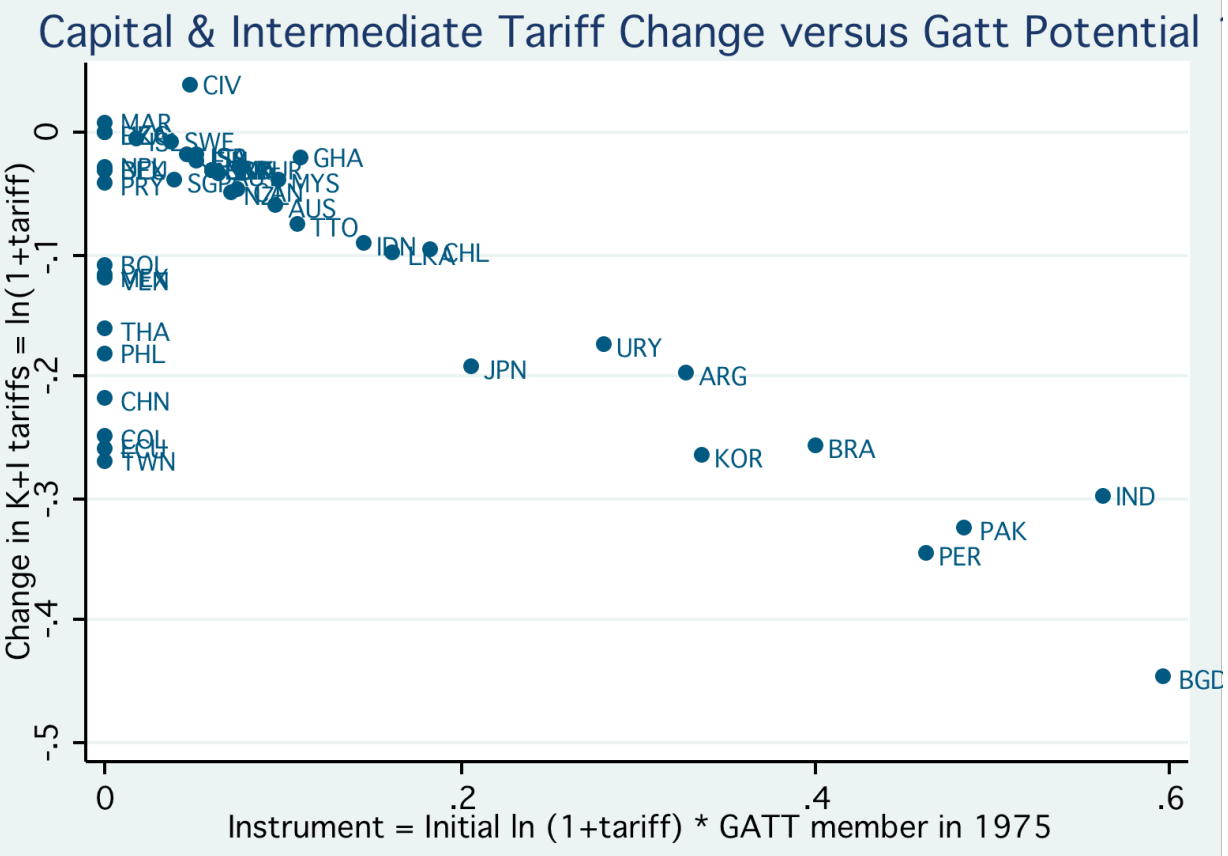

(b) Bivariate Scatter of change in tariff versus GATT Potential 2 using Great Depression intensity times log initial tariff

Capital \& Intermediate Tariff Change versus Gatt Potential :

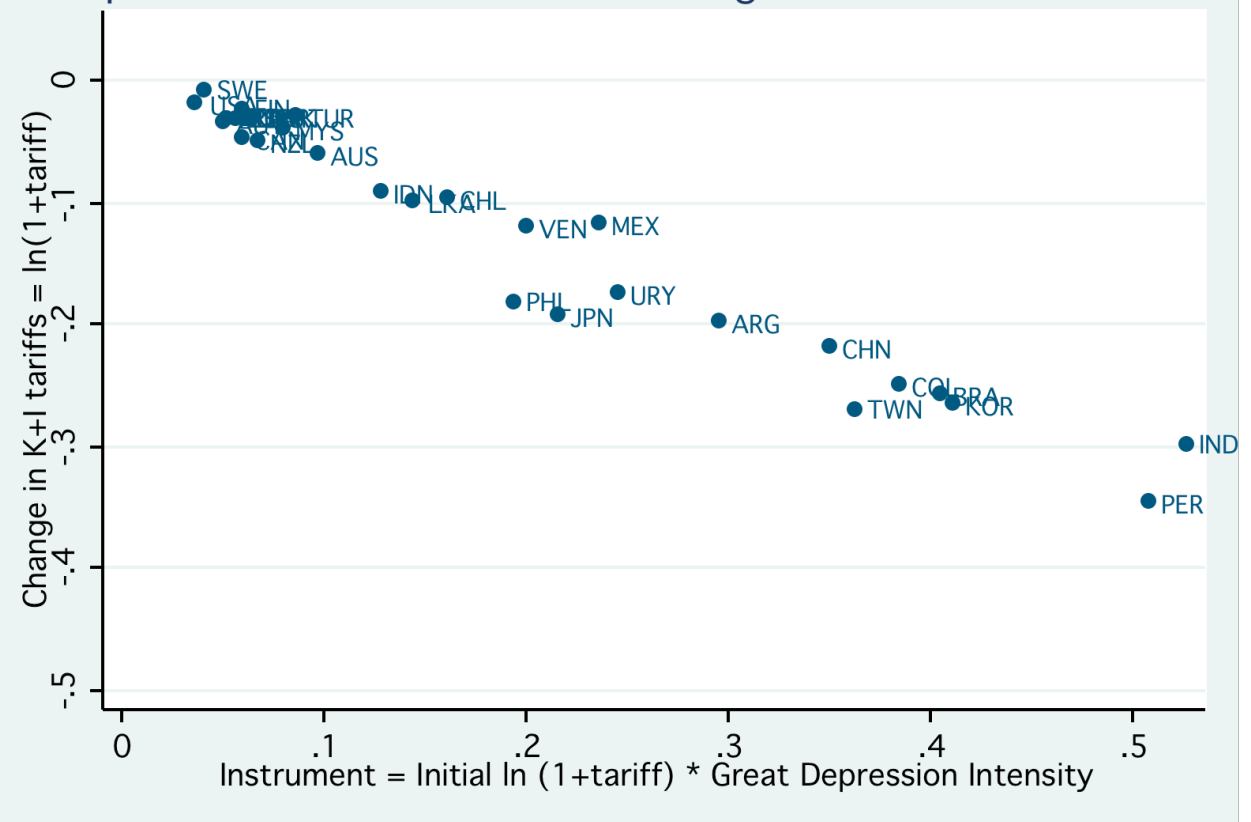


Figure 6: The Great Liberalization and Growth Accelerations

Log income per worker (PWT) relative to 1975-89 trend in liberalizers and nonliberalizers

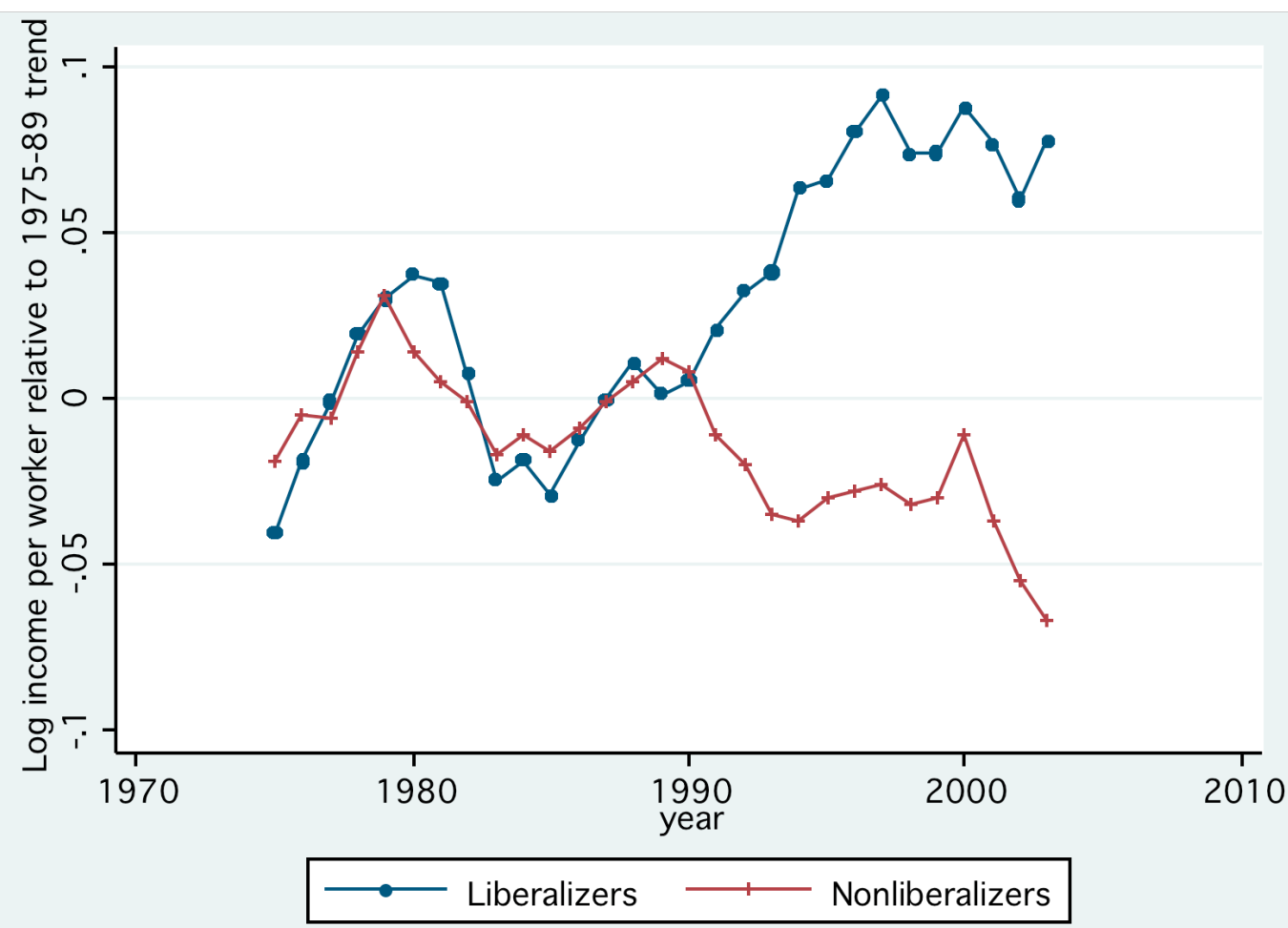

Notes: The samples are as in Figure 4, based on changes in tariffs for capital and intermediate goods. 


\section{Appendix}

Appendix Table 1 shows the sources for disaggregated data on tariffs for this sample of countries in the early (ca. 1985) and late (ca. 2000) benchmark years.

Compilation of disaggregated tariff data is a key component of our empirical research strategy in this study. We use a newly constructed tariff dataset for 37 countries in two benchmarks periods: a preliberalization period (circa mid-1980s) and a post liberalization period (circa 2000). The sample includes: Argentina, Australia, Belgium-Luxembourg, Bolivia, Brazil, Canada, Chile, China, Colombia, Denmark, Ecuador, France, Germany, Hong Kong (China), India, Indonesia, Italy, Japan, Korea (Republic of), Malaysia, Mexico, Netherlands, New Zealand, Pakistan, Paraguay, Peru, Philippines, Singapore, Spain, Sweden, Taipei (China), Thailand, Turkey, United Kingdom, United States, Uruguay, and Venezuela.

We use for both periods Most Favored Nation (MFN) applied customs duty. For the late benchmark we rely on pre-compiled tariff data by the UNCTAD's TRAINS (Trade Analysis and Information System). However, for the earliest benchmark, UNCTAS's TRAINS only covers 11 countries in our sample. Tariff data for a number of European Union countries are based on UNCTAD's TRAINS complemented with EU Tariff Schedules. For the rest of the sample we had no option but to collect the tariff data by hand, line by line, from national tariff schedules from the 1980s. Tariff data for all Latin American Countries (Argentina, Bolivia, Brazil, Chile, Colombia, Ecuador, Mexico, Paraguay, Peru, Uruguay, and Venezuela) comes from national customs schedules provided by ALADI.

For China, Korea, Pakistan, Philippines, Japan, Singapore, Taipei (China) we used (scanned and translated) published national tariff schedules available at the Library of Congress (Washington, D.C.):

- China: The official Chinese customs guide, General Office of the Customs General Administration of the People's Republic of China, 1985/1986.

- Japan: Customs tariff schedules of Japan, Nihon Kanzei Kyokai, 1985.

- Korea (Republic): Korea customs law and regulations, Korea Customs Research Institute, 1984.

- Pakistan: Pakistan customs tariff and import trade guide, Karachi Law Publishers, 1985-1986.

- Philippines: Commentaries on the revised Tariff and Customs Code of the Philippines: P.D. no. 1464, as amended by Executive order no. 688, Central Lawbook Pub. Co., 1983.

- Singapore: Singapore Trade Classification and Customs Duties, Trade Development Board (Singapore), 1985

- Taipei (China): Customs import tariff of the Republic of China: revised edition, Jan. 1985., Hai guan zong shui wu si shu, 1985.

In general, the tariff data were obtained in national nomenclatures based on the Harmonized System nomenclature (HS). The data had to be averaged out into 6-digit HS Sub-headings, and then each 6-digit tariff line were linked to their corresponding codes using the UN Broad Economic Categories (BEC) classification by means of conversion tables for the 1988 and 2006 versions of the HS, also obtained from WITS. Finally, the BEC categories were mapped out to the System of National Accounts (SNA) categories to distinguish between capital, intermediate and consumption goods.

For the purposes of this research project we had to make some adjustments of the SNA categories. The concordance procedure for the early benchmark was especially difficult since it varied according to the source of the data. Tariff data for Latin American countries was usually provided in NALADISA nomenclature and it had to be correlated first into Standard International Trade Classification (SITC, Rev. 2 ), and then converted into BEC and SNA. Tariff data for other countries (national schedules) used generally the Customs Cooperation Council Nomenclature (CCCN), the predecessor to the HS. For these data, a conversion table had to be produced manually connecting the CCCN to the SNA categories via the SITC and BEC. In particular, tariff schedules for China and Pakistan were not fully consistent with the standard CCCN, so ad-hoc conversions and assumptions had to be made for these two countries. 


\section{Appendix Table 1: Sources for Disaggregated Tariffs}

\begin{tabular}{|c|c|c|c|c|}
\hline \multirow{2}{*}{$\begin{array}{l}\text { Country } \\
\text { Name }\end{array}$} & \multicolumn{3}{|c|}{ MFN Tariff Data ${ }^{1}$} & \multirow{2}{*}{$\begin{array}{c}\text { Early Benchmark in } \\
\text { TRAINS }\end{array}$} \\
\hline & Late Benchmark & Early Benchmark & Source for Early Benchmark & \\
\hline Argentina & 2000 & 1985 & NAT & 1992 \\
\hline Algeria & 2001 & 1992 & TRAINS & \\
\hline Australia & 2000 & 1991 & TRAINS & \\
\hline Austria & 2000 & 1990 & TRAINS & \\
\hline Bangladesh & 2000 & 1989 & TRAINS & \\
\hline Belgium-Luxembourg* & 2000 & 1988 & TRAINS-EU & \\
\hline Bolivia & 2000 & 1985 & NAT & 1993 \\
\hline Brazil & 2000 & 1985 & NAT & 1989 \\
\hline Canada & 2000 & 1989 & TRAINS & \\
\hline Chile & 2000 & 1985 & NAT & 1992 \\
\hline China & 2000 & 1985 & NAT & 1992 \\
\hline Colombia & 2000 & 1985 & NAT & 1991 \\
\hline Côte d'Ivoire & 2001 & 1993 & TRAINS & \\
\hline Denmark & 2000 & 1988 & TRAINS-EU & \\
\hline Ecuador & 1999 & 1985 & NAT & 1993 \\
\hline Finland & 2000 & 1988 & TRAINS & \\
\hline France & 2000 & 1988 & TRAINS-EU & \\
\hline Germany** & 2000 & 1988 & TRAINS-EU & \\
\hline Ghana & 2000 & 1993 & TRAINS & \\
\hline Hong Kong & 1998 & 1988 & TRAINS & \\
\hline Iceland & 2001 & 1993 & TRAINS & \\
\hline India & 1999 & 1990 & TRAINS & \\
\hline Indonesia & 2000 & 1989 & TRAINS & \\
\hline Israel & 2004 & 1993 & TRAINS & \\
\hline Italy & 2000 & 1988 & TRAINS-EU & \\
\hline Japan & 2000 & 1985 & NAT & 1988 \\
\hline Korea, Rep. & 1999 & 1985 & NAT & 1988 \\
\hline Malaysia & 2001 & 1988 & TRAINS & \\
\hline Mexico & 2000 & 1985 & NAT & 1991 \\
\hline Morocco & 2000 & 1993 & TRAINS & \\
\hline Nepal & 2000 & 1993 & TRAINS & \\
\hline Netherlands & 2000 & 1988 & TRAINS-EU & \\
\hline New Zealand & 2000 & 1992 & TRAINS & \\
\hline Pakistan & 2001 & 1985 & NAT & 1995 \\
\hline Paraguay & 2000 & 1985 & NAT & 1991 \\
\hline Peru & 2000 & 1985 & NAT & 1993 \\
\hline Philippines & 2000 & 1985 & NAT & 1988 \\
\hline Singapore & 2001 & 1985 & NAT & 1989 \\
\hline Spain & 2000 & 1988 & TRAINS-EU & \\
\hline Sri Lanka & 2000 & 1990 & TRAINS & \\
\hline Sweden & 2000 & 1988 & TRAINS & \\
\hline Taiwan & 2000 & 1985 & NAT & 1989 \\
\hline Thailand & 2000 & 1989 & TRAINS & \\
\hline
\end{tabular}




\begin{tabular}{lccc}
\hline Trinidad and Tobago & 2001 & 1991 & TRAINS \\
Turkey & 1999 & 1993 & TRAINS \\
United Kingdom & 2000 & 1988 & TRAINS-EU \\
United States & 2000 & 1989 & TRAINS \\
Uruguay & 2000 & 1985 & NAT \\
Venezuela & 2000 & 1985 & NAT \\
Notes: Source of MFN tariff data is TRAINS for the late benchmark, and ALADI, TRAINS, and National Sources in the early \\
benchmark. EU tariff data is disaggregated by product at a greater level of digits in TRAINS than trade data. TRAINS = \\
UNCTAD-TRAINS (Trade Analysis and Information System). TRAINS-EU = The EU schedule of tariffs according to TRAINS. \\
NAT = National sources. \\
$*$ Belgium and Luxembourg are treated as separate countries starting in 1999. Trade for both countries was queried separately \\
and then aggregated for years 1998 and earlier. \\
$* *$ East Germany (DDR) is excluded from Germany data for years 1990 and prior; BEC and SITC Rev.1 leaf-level data is not \\
available for DDR.
\end{tabular}

